Check for updates

Cite this: RSC Adv., 2019, 9, 29273

Received 4th July 2019

Accepted 6th September 2019

DOI: $10.1039 / c 9 r a 05059 k$

rsc.li/rsc-advances

\section{Design, synthesis and biological evaluation of 1,2,3- triazole based 2-aminobenzimidazoles as novel inhibitors of LasR dependent quorum sensing in Pseudomonas aeruginosa $\dagger$}

Singireddi Srinivasarao, ${ }^{a}$ Adinarayana Nandikolla, ${ }^{a}$ Shashidhar Nizalapur, ${ }^{\mathrm{b}}$ Tsz Tin Yu, ${ }^{\mathrm{b}}$ Sravani Pulya, ${ }^{\text {C }}$ Balaram Ghosh, ${ }^{C}$ Sankaranarayanan Murugesan, ${ }^{d}$ Naresh Kumar (D) b and Kondapalli Venkata Gowri Chandra Sekhar (iD *a

Bacteria regulate their phenotype, growth and population via a signalling pathway known as quorum sensing. In this process, bacteria produce signalling molecules (autoinducers) to recognize their population density. Inhibiting this quorum sensing signalling pathway is one of the potential methods to treat bacterial infection. 2-Aminobenimdazoles are reported to be the strongest inhibitors of quorum sensing against wild-type $P$. aeruginosa. 1,2,3-Triazole based acyl homoserine lactones are found to be good inhibitors of the quorum sensing LasR receptor. Hence, in our current study, forty 1,2,3-triazole based 2-aminobenzimdazoles were synthesized and characterized using IR, NMR, MS and elemental analysis. A single crystal was developed for $N$-(1H-benzo[d]imidazol-2-yl)-2-(4-nonyl-1H-1,2,3-triazol-1-yl)acetamide (6d). All final compounds were screened for in vitro quorum sensing inhibitory activity against Pseudomonas aeruginosa. The quorum sensing inhibitory activity was determined in the LasR expressing $P$. aeruginosa MH602 reporter strain by measuring green fluorescent protein production. Among the title compounds, $\mathrm{N}$-(1H-benzo[d]imidazol-2-yl)2-(4-(4-chlorophenyl)-1H-1,2,3-triazol-1-yl)acetamide (6i) exhibited good quorum sensing inhibitory activity of $64.99 \%$ at $250 \mu \mathrm{M}$. N-(1H-Benzo[d] imidazol-2-yl)-2-(4-(4-nitrophenyl)-1H-1,2,3-triazol-1-yl)acetamide (6p) exhibited the most promising quorum sensing inhibitory activity with $68.23,67.10$ and $63.67 \%$ inhibition at 250, 125 and $62.5 \mu \mathrm{M}$, respectively. $N$-(1H-Benzo[d] imidazol-2-yl)-2-(4-(4-(trifluoromethyl)phenyl)-1H-1,2,3triazol-1-yl)acetamide (6o) and $N$-(5,6-dimethyl-1H-benzo[d]imidazol-2-yl)-2-(4-(4-(trifluoromethyl)phenyl)$1 H$-1,2,3-triazol-1-yl)acetamide (7l) also exhibited $64.25 \%$ and $65.80 \%$ quorum sensing inhibition at $250 \mu \mathrm{M}$. Compound $6 \mathrm{p}$, the most active quorum sensing inhibitor, also displayed low cytotoxicity at the tested concentrations $(25,50$ and $100 \mu \mathrm{M})$ against normal human embryonic kidney cell lines. Finally, a docking study using Schrodinger Glide elucidated the possible putative binding mode of the significantly active compound $6 p$ at the active site of the target LasR receptor (PDB ID: 2UV0).
${ }^{a}$ Department of Chemistry, Birla Institute of Technology and Science, Pilani, Hyderabad Campus, Jawahar Nagar, Kapra Mandal, Hyderabad - 500078, Telangana, India.E-mail: kvgc@hyderabad.bits-pilani.ac.in; kvgcs.bits@gmail.com; Tel: +914066303527

${ }^{b}$ School of Chemistry, UNSW Sydney, NSW 2052, Australia

'Department of Pharmacy, Birla Institute of Technology and Science, Pilani, Hyderabad Campus, Jawahar Nagar, Kapra Mandal, Hyderabad-500078, Telangana, India

${ }^{d}$ Medicinal Chemistry Research Laboratory, Department of Pharmacy, Birla Institute of Technology and Science, Pilani, 333031, India

$\uparrow$ Electronic supplementary information (ESI) available: Experimental procedures for intermediates (chemistry) and spectroscopic/analytical data. CCDC 1904042. For ESI and crystallographic data in CIF or other electronic format see DOI: 10.1039/c9ra05059k

\section{Introduction}

Many pathogenic bacteria use signaling strategies to multiply their number in a process known as Quorum sensing (QS). In this process, bacteria produce and release chemical signaling molecules, known as auto-inducers (AIs). These signaling chemical molecules play a vital role in both bacterial virulence and symbiosis and have a noteworthy impact on human health, cultivation and the environment. ${ }^{1-3}$ At high bacterial cell density, bacteria alter gene expression levels to coordinate assorted behaviors, including biofilm formation, virulence factor production, bioluminescence, conjugation, sporulation, etc. ${ }^{4-7}$ Gram-negative bacteria cause several nosocomial infections including bloodstream infections, pneumonia, wound or surgical site infections. ${ }^{89}$ P. aeruginosa, an opportunistic pathogen and second leading cause of ventilator associated 
pneumonia is responsible for several serious infections in immune compromised patients, chronic lung infection (cystic fibrosis) and for the most common fatal communicable disease. ${ }^{10-13}$ As $P$. aeruginosa develops resistant to available carbapenem and other antibiotics, it is listed as critical by the World Health Organization. ${ }^{\mathbf{1 4}}$ Bacterial resistance may cause prolonged hospitalization, expensive medical costs and increase in mortality and hence, there is an urgent need to look out for non-antibiotic solutions to manage invasive bacterial infections and QS could be a potential solution. QSIs are attractive alternatives to replace the conventional antibiotics to minimize the development of bacterial resistance. ${ }^{15,16}$ So far, many QSIs have been reported but only very few entered clinical trials. ${ }^{17}$ Many proteobacteria which includes $P$. aeruginosa use $N$-acylated-L-homoserine lactones (AHLs/AIs) as QS signaling molecules. ${ }^{18}$ (Fig. 1).

P. aeruginosa uses LasI/LasR, RhlI/RhlR and PQS/MvfR QS systems to alter gene expression and is responsible for prolonged hospitalization and high mortality in hospital patients. ${ }^{19-21} \quad \mathrm{~N}$-(3-Oxododecanoyl)-L-homoserine lactone (OdDHL) and $N$-butanoyl-L-homoserine lactone (BHL) are the AIs of $P$. aeruginosa (Fig. 2). ${ }^{22}$

\section{Design}

Several AHL and non-AHL based QSIs against $P$. aeruginosa are reported till date. ${ }^{23,24}$ Biofilm formation of pathogenic bacteria occurs at high cell-density and higher cell density is responsible for QS. ${ }^{25-27}$ Based on this, Blackwell group identified two most active biofilm inhibitors, 2-aminobenzimidazole (I) and 5,6dimethyl-2-aminobenzimidazole (II) and evaluated for QSI activity against wild-type $P$. aeruginosa QS reporter strains. Among these, compound II possesses higher inhibition against Las and Rhl QS systems with $\mathrm{IC}_{50}$ values $37.5 \mu \mathrm{M}$ and $12.5 \mu \mathrm{M}$ respectively. ${ }^{28,29}$ Furthermore, the same group reported that compound II is a potential inhibitor of LasR activity with $\mathrm{IC}_{50}$ $2.3 \mu \mathrm{M}$ against $P$. aeruginosa PAO-JP2 and $1.4 \mu \mathrm{M}$ against $P$. aeruginosa PAO-JG21 (Fig. 3). ${ }^{29}$

1,2,3-Triazoles are reported as QSIs, antitubercular agents, fluorinated hydrogels and their applications in radiochemistry was also studied previously. ${ }^{30-35}$ In 2013 , Stacy et al. reported AHL based 1,2,3-triazoles as QSIs, in which, they retained the lactone ring of AHL and its amide bond and modified the side chain with various substituted 1,2,3-triazoles and reported effective QSIs against $P$. aeruginosa. Further, they have clearly highlighted that inclusion of triazoles led to superior activity than their counter parts against LasR. ${ }^{31}$ Compounds III and IV are the most active QS inhibitors (Fig. 3), with 75\% QS
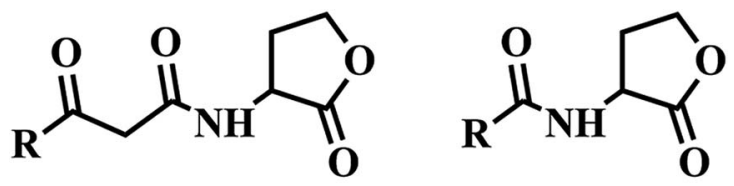

\section{$N$-acyl homoserine lactones (AHLs/AIs)}

Fig. 1 Autoinducers in proteobacteria. inhibition at $100 \mu \mathrm{M}$. In conclusion, this group noticed that compounds with methylene group between $N$-acyl group and 1,2,3-triazole nucleus is indispensable for QSI activity, ${ }^{31}$ while compounds with absence of methylene group and $N$-acyl group exhibited poor QSI activity (compounds $\mathbf{V}$ and VI). ${ }^{32,33}$ Compounds VII and VIII are active QSIs with 50.7\% and 49.7\% inhibition at $250 \mu \mathrm{M}$ against $P$. aeruginosa $\mathrm{MH} 602$ respectively. ${ }^{34}$ In another recent work, two methylene linkers retained between triazole nucleus and $N$-acyl-2-phenyl indole gave the most active QSI with $60.8 \%$ inhibition at $250 \mu \mathrm{M}$ against $P$. aeruginosa MH602 (compound IX). ${ }^{24}$ Compound $\mathbf{X}$, with one methylene linker, is an another active QSI with $74.2 \%$ inhibition at 250 $\mu \mathrm{M} .{ }^{35}$ Based on these results, we retained at least one methylene linker between 1,2,3-triazole and $N$-acyl cycloalkane and designed the compounds of the current scheme (Fig. 3). 1,2,3Triazole based QSIs are summarized in Table 1.

Enthused by the QSI active molecules of 2-aminonobenzimdazoles and 1,2,3-triazole analogues, we incorporated these active pharmacophores into one framework, and synthesized non-AHL based QSIs, as shown in Fig. 3. In this work, we synthesized various substituted 1,2,3-triazoles of $\mathrm{N}$-(1H-benzo [d]imidazol-2-yl) and $N$-(5,6-dimethyl- $1 H$-benzo[d]imidazol-2-yl) acetamide, propanamide and butamides and screened them for their QSI activity against $P$. aeruginosa MH602 strain. Several $N$-acyl analogues of cyclopentyl, cyclohexyl and amino pyridines also exhibited promising QSI activity against $P$. aeruginosa. ${ }^{34}$ Hence, as a part of this work, we also introduced triazole based $\mathrm{N}$-acyl cyclopentane, cyclohexane and pyridine as the tail groups of aminobenzimdazole to gauge their importance in exhibiting QS inhibition.

\section{Results and discussion}

\section{Chemistry}

As shown in Scheme 1, first compounds $2 \mathbf{a}$ and $\mathbf{2 b}$ were prepared according to literature procedure from starting materials $\mathbf{1 a}$ and $\mathbf{1 b}$ respectively. ${ }^{36} \mathbf{2 a}$ and $\mathbf{2 b}$ upon treatment with chloroacetyl chloride yielded $N$-acyl compounds $\mathbf{3 a}$ and $\mathbf{3} \mathbf{b}$ respectively. To obtain fourth intermediate, compounds $\mathbf{5 a}$ and $\mathbf{5 b}$ from second $\mathbf{3 a}$ and $\mathbf{3} \mathbf{b}$, we initially performed several reactions by varying the reaction conditions, which includes the use of different solvents (acetonitrile, tetrahydrofuran, dimethylformamide etc.) and temperatures. All these conditions required high temperatures and seal tube/microwave irradiation with long time. Furthermore, KI was used as the catalyst (Finkelstein reaction) and the reaction was carried out in an aprotic solvent in seal tube at $120{ }^{\circ} \mathrm{C}$. It took $72 \mathrm{~h}$ for the reaction to proceed but only gave $35 \%$ yield. Since satisfactory yields were not obtained even after varying the conditions, we decided to synthesize $\mathbf{5 a}$ and $\mathbf{5 b}$ in two steps. $\mathbf{3} \mathbf{a}$ and $\mathbf{3 b}$ were dissolved in acetone and water to give a clear solution, followed by the addition of 1.2 equivalent of $\mathrm{KI}$ and the reaction mixture was heated up to $55{ }^{\circ} \mathrm{C}$ for $12 \mathrm{~h}$. On completion of reaction, as indicated by TLC, $\mathbf{4 a}$ and $\mathbf{4 b}$ were isolated. Then pre-final azides $\mathbf{5 a}$ and $\mathbf{5 b}$ were prepared from $4 \mathbf{a}$ and $\mathbf{4 b}$ using $\mathrm{NaN}_{3}$. Final compounds $\mathbf{6 a - q}$ from $5 \mathbf{a}$ and $7 \mathbf{a}-\mathbf{n}$ from $\mathbf{5 b}$ were obtained on treatment with various acetylenes in $45-91 \%$ yield (Scheme 1). 
<smiles>CCCCCCCCCC(=O)CC(=O)NC1CCOC1=O</smiles>

OdDHL<smiles>CCCC(=O)NC1CCOC1=O</smiles>

BHL

Fig. 2 Auto-inducers in $P$. aeruginosa.

As shown in Scheme 2, in order to get amides 9a-c, we performed acid-amine coupling reaction using $\mathrm{EDC} \cdot \mathrm{HCl}$ and $\mathrm{HOBt}$ as coupling reagents. Compound 9a was prepared from $1 \mathrm{H}^{-}$ benzo[ $d]$ imidazol-2-amine (2a) and pent-4-ynoic acid (8a). Similarly, $\mathbf{2 a}$ and $\mathbf{2 b}$ on treatment with hex-5-ynoic acid (8b) yielded compounds $\mathbf{9 b}$ and $\mathbf{9 c}$ respectively. Finally, the $\mathbf{9 a}, \mathbf{9 b}$ and 9c on treatment with various substituted azides using copper sulphate pentahydrate as catalyst gave 10a-b, 11a-d and 12a-c in $45-68 \%$ yield.

Most of the azides required for triazole preparation were procured commercially. However, azides A, B and $\mathbf{C}$ required for the preparation of the final derivatives of Series-III were accomplished via Scheme 3.
The purity of the synthesized compounds was assessed by LC-MS and elemental analyses. Structures of the compounds were confirmed by spectral data. In ${ }^{1} \mathrm{H}$ NMR and ${ }^{13} \mathrm{C}$ NMR, the signals of the corresponding protons and carbon atoms were verified based on their chemical shift, multiplicities and coupling constant values. The results of elemental analysis were within \pm 0.05 of the theoretical values.

${ }^{1} \mathrm{H}$ NMR spectra of compounds $\mathbf{6 a}-\mathbf{q}$ and $7 \mathbf{a}-\mathbf{n}$ from Scheme 1 showed singlet which integrates to two protons at 5-6 ppm due to the active methylene $\mathrm{CH}_{2}$, whereas the methylene protons for compounds 10-12 from Scheme 2 were observed at more up field (at around 1.5 to $3.5 \mathrm{ppm}$ ) due to a larger separation of methylene protons from $\mathrm{N}$-acyl group and triazole nucleus. All final compounds from Schemes 1 and 2 have

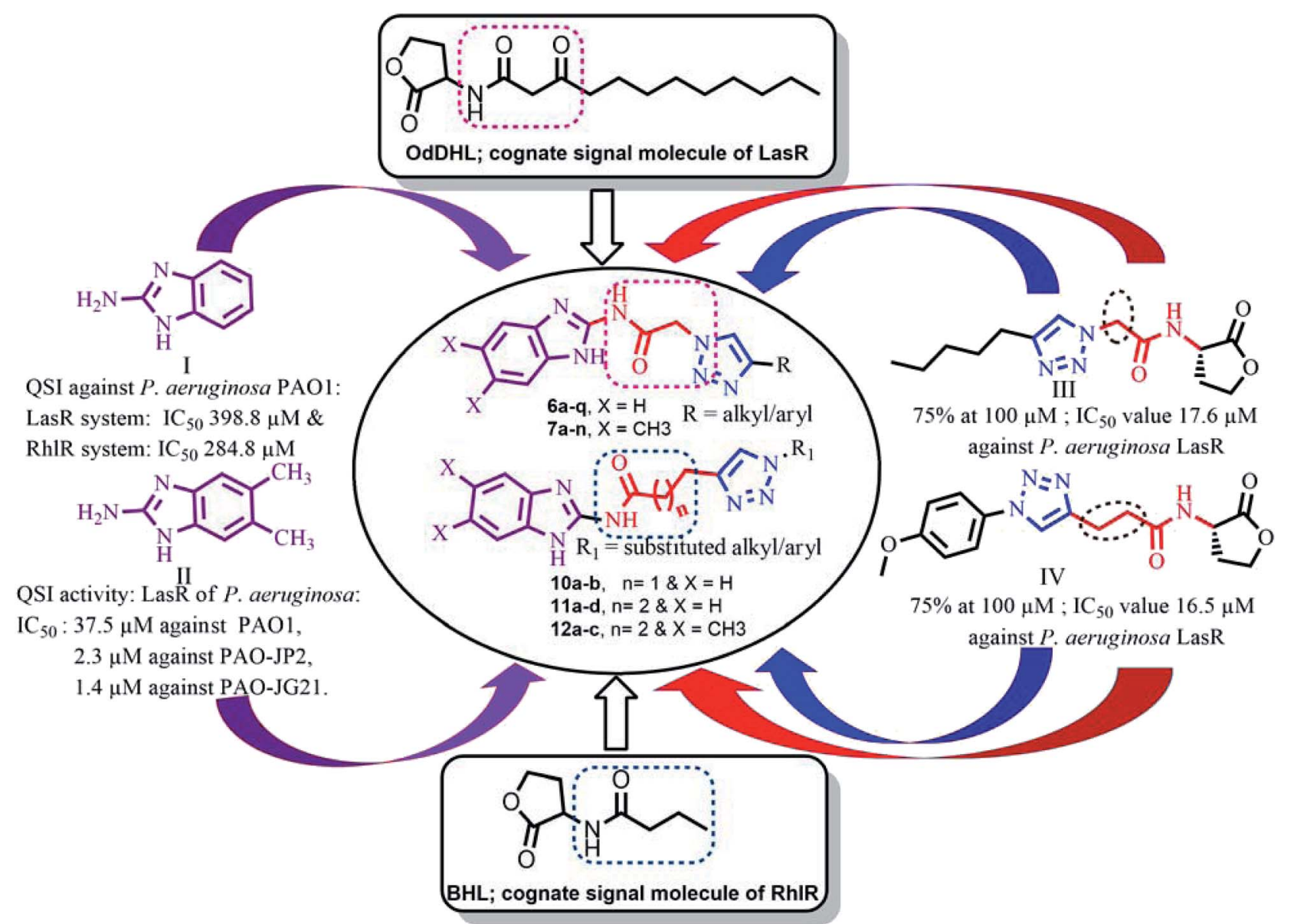

Fig. 3 Design strategy for the synthesis of titled quorum sensing inhibitors. 
Table 1 1,2,3-Triazole based QSIs against $P$. aeruginosa reported from literature

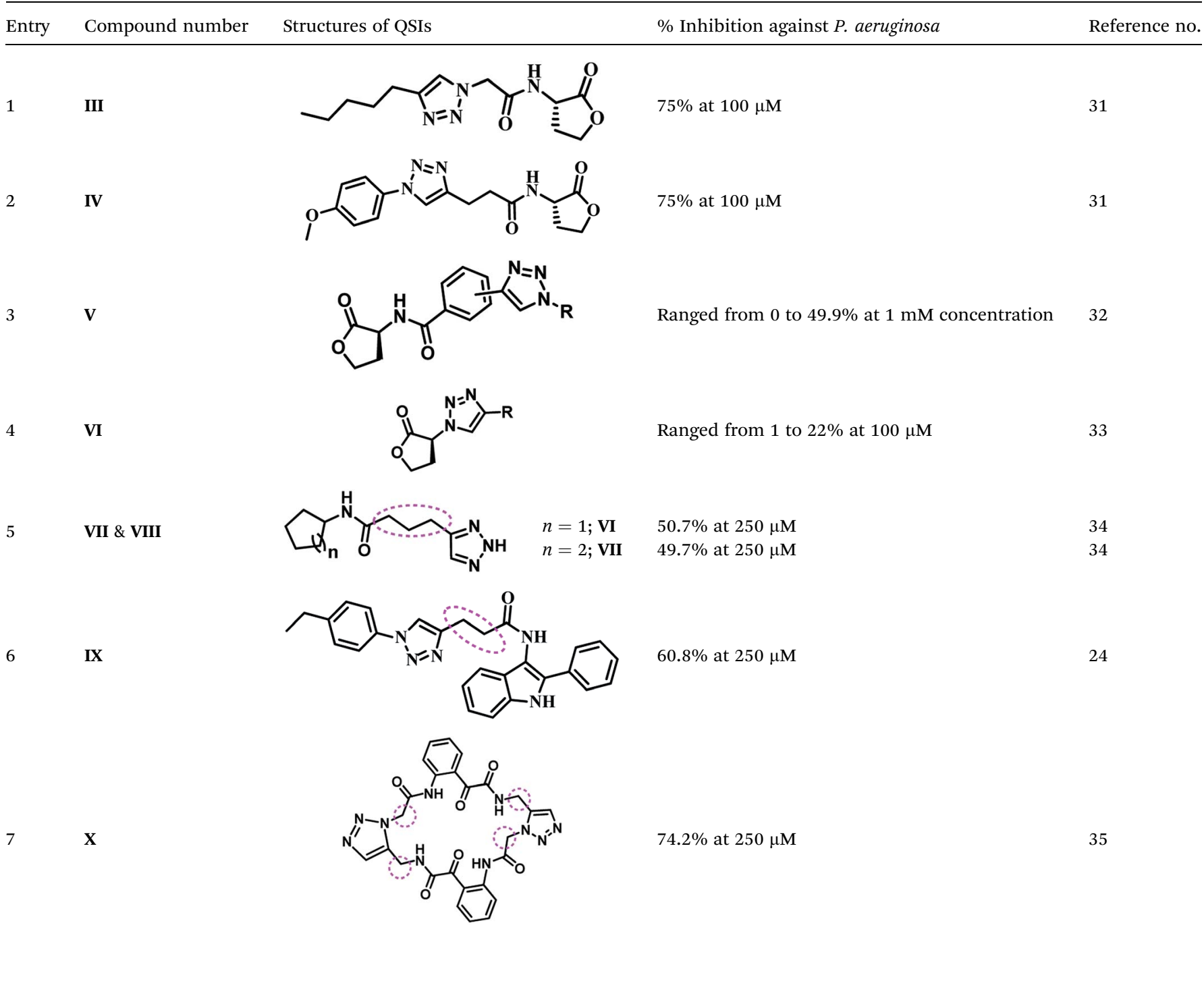<smiles></smiles>

1a, $\mathrm{X}=\mathrm{H}$ 1b, $\mathrm{X}=\mathrm{CH}_{3}$<smiles>O=C(Cl)CCl</smiles>

(ii)

2a, $X=\mathrm{H}$

2b, $\mathrm{X}=\mathrm{CH}_{3}$<smiles>[X]c1cc2nc(NCO)[nH]c2cc1[X]</smiles>

3a, $\mathrm{X}=\mathrm{H}$ 3b, $\mathrm{X}=\mathrm{CH}_{3}$<smiles>[X]c1cc2nc(NC(=O)CI)[nH]c2cc1[X]</smiles>

(iii)

$4 a, X=H$

4b, $\mathrm{X}=\mathrm{CH}_{3}$

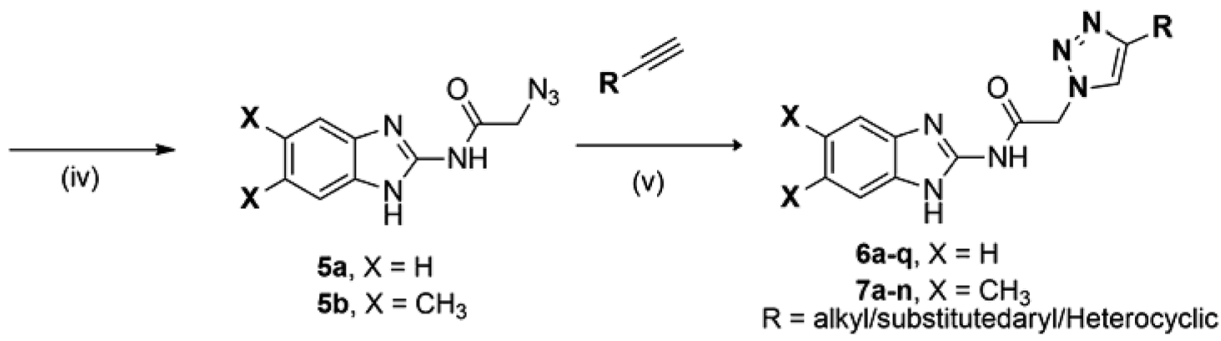

Scheme 1 General synthetic route for compounds $6 a-q$ and $7 a-n$. Reagents and conditions: (i) cyanogen bromide (1.1 eq.), methanol, reflux, $5 \mathrm{~min}$; (ii) chloroacetyl chloride (1.0 eq.), pyridine (2.5 eq.), $\mathrm{CH}_{2} \mathrm{Cl}_{2}, 0^{\circ} \mathrm{C}-\mathrm{rt}, 12 \mathrm{~h}$; (iii) potassium iodide (1.2 eq.), acetone, $55^{\circ} \mathrm{C}, 12 \mathrm{~h}$; (iv) $\mathrm{NaN}$ (1.5 eq.), DMF : water $(8: 2), 0{ }^{\circ} \mathrm{C}$; (v) substituted terminal alkynes (1.4 eq.), $\mathrm{CuSO}_{4} \cdot 5 \mathrm{H}_{2} \mathrm{O},(5 \mathrm{~mol} \%)$, sodium ascorbate (10 mol\%), DMF : water (8 : 2$)$, $\mathrm{rt}, 6-16 \mathrm{~h}$. 


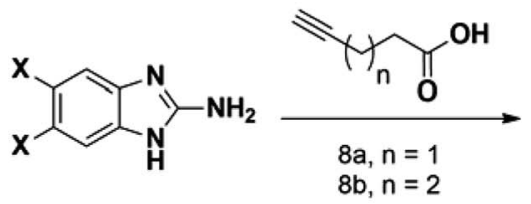

2a, $\mathrm{X}=\mathrm{H}$

2b, $\mathrm{X}=\mathrm{CH}_{3}$ (vi)

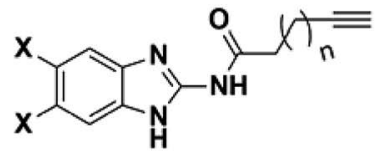

(vii)

$$
\begin{aligned}
& 9 a, n=1 \& X=H \\
& 9 b, n=2 \& X=H \\
& 9 c, n=2 \& X=\mathrm{CH}_{3}
\end{aligned}
$$

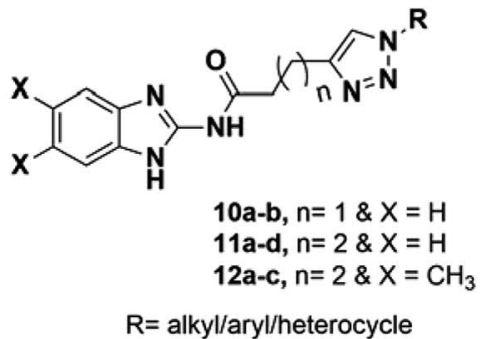

$\mathrm{R}=\mathrm{alkyl} / \mathrm{ary} / \mathrm{heterocycle}$

Scheme 2 General synthetic route for compounds 10a-b, 11a-d and 12a-c. Reagents and conditions: (vi) $2 \mathrm{a}$ or $2 \mathrm{~b}(1.0 \mathrm{eq}$ ), EDC.HCl (1.5 eq.) HOBt, (1.5 eq.) diisopropyl ethylamine (2.5 eq.), DMF, rt, 16 h; (vii) 9a/9b/9c and substituted azides (1.5 eq.), $\mathrm{CuSO}_{4} \cdot 5 \mathrm{H}_{2} \mathrm{O},(10 \mathrm{~mol} \%$ ), sodium ascorbate (10 mol\%), DMF : water (8:2), rt, 6-16 h.

triazole nucleus, benzimidazole $\mathrm{N}-\mathrm{H}$ and amide $\mathrm{N}-\mathrm{H}$, in which the proton of triazole nucleus was observed at around 8.2$9.2 \mathrm{ppm}$ as singlet, and the $\mathrm{N}-\mathrm{H}$ protons of amide and imidazole were observed as broad singlets at 11-14 ppm. Furthermore, single crystal was developed for compound $\mathbf{6 d}$.

\section{Biological activity}

Series of triazole based benzimidazole derivatives $(\mathbf{6 a}-\mathbf{q}, 7 \mathbf{7}-\mathbf{n}$, 10a-b, 11a-d and 12a-c) were analyzed for their QS-inhibition activity at various concentrations $(62.5,125 \& 250 \mu \mathrm{M})$ against $P$. aeruginosa MH602 lasB reporter strain [PlasB: gfp(ASV)] following the protocol developed by Hentzer et al. ${ }^{37}$ The production of AHL signals by this reporter strain leads to an increase in the production of unstable green fluorescent protein (GFP-ASV) as a function of an active QS system. Considering this fact, synthesis of benzimidazole triazole analogues has been prioritized to counteract the QS system. The results are compiled in Table 2.

\section{Predictive structure-activity relationship study (SAR)}

In the first series (Series-I in Table 2), benzimidazoles 6a-q with no substitution on the benzene ring were undertaken. The effect of alkyl chain length on the triazole partner of the molecule was first studied. It was found that changing the lipophilicity by altering the length of the alkyl chain on triazole ring has no significant effect on the QSI activities of the compound as compounds 6a-d possess similar percentage of QS inhibition within different tested concentrations. The effect of attaching a terminal heterocyclic group on the triazole partner of the molecule was then studied. While attaching a 2-methylthiobenzimidazole onto the triazole ring (6e) gave a similar QSI activity $(41.31 \%$ inhibition at $250 \mu \mathrm{M})$ as compounds $6 \mathbf{6}-$ d (42.76-50.50\% inhibition at $250 \mu \mathrm{M})$, it was found that attaching 5-chloro-pyridone on the triazole nucleus (6f) enhanced the QSI activity of benzimidazole to $58.84 \%$ at 250 $\mu \mathrm{M}$. The QSI activities of benzimidazoles having various substituted aryl groups on triazole nucleus $(\mathbf{6 g}-\mathbf{q})$ were also investigated. Halo-substitution at the para-position of aryls on the triazole nucleus $(\mathbf{6 h}-\mathbf{j})$ showed promising QSI activity even at low concentration $(>45.00 \%$ inhibition at $62.5 \mu \mathrm{M})$ when compared to its un-substituted parent molecule $\mathbf{6 g}$, with only $15.10 \%$ inhibition at $62.5 \mu \mathrm{M}$. Furthermore, among these haloaryl derivatives, chloro-derivative (6i) exhibited the highest QSI activity at all concentrations. Alkyl groups substituted at the para-position of aryl ring (6k-1) diminished the QSI activity of the benzimidazoles. In fact, when a tert-butyl group was placed on the aryl ring of the triazole nucleus, the corresponding benzimidazole (61) showed no QSI activity at lower concentrations. To study the effect of aryl rings carrying electron-releasing groups on the QSI activity, benzimidazoles $\mathbf{6 m}$ and $\mathbf{6 n}$ bearing a phenol and anisole group, respectively, were tested.

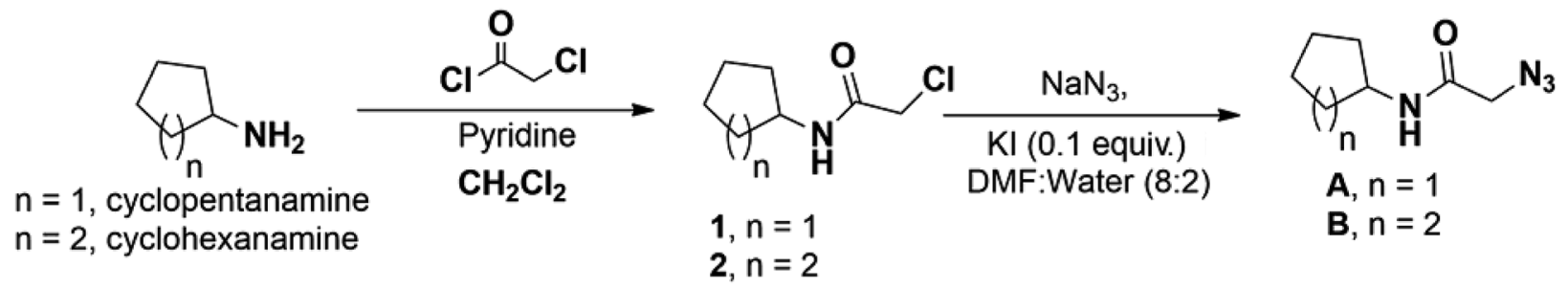

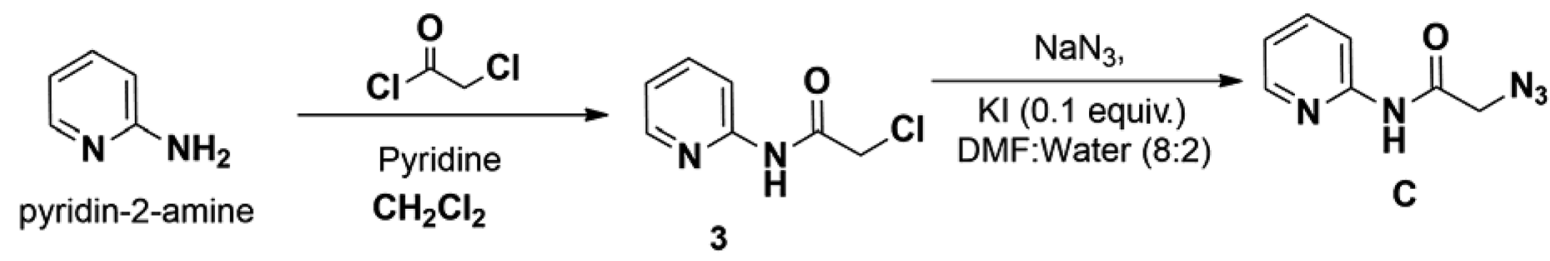


Table 2 Percentage inhibition of GFP fluorescence by the synthesized compounds against $P$. aeruginosa MH602

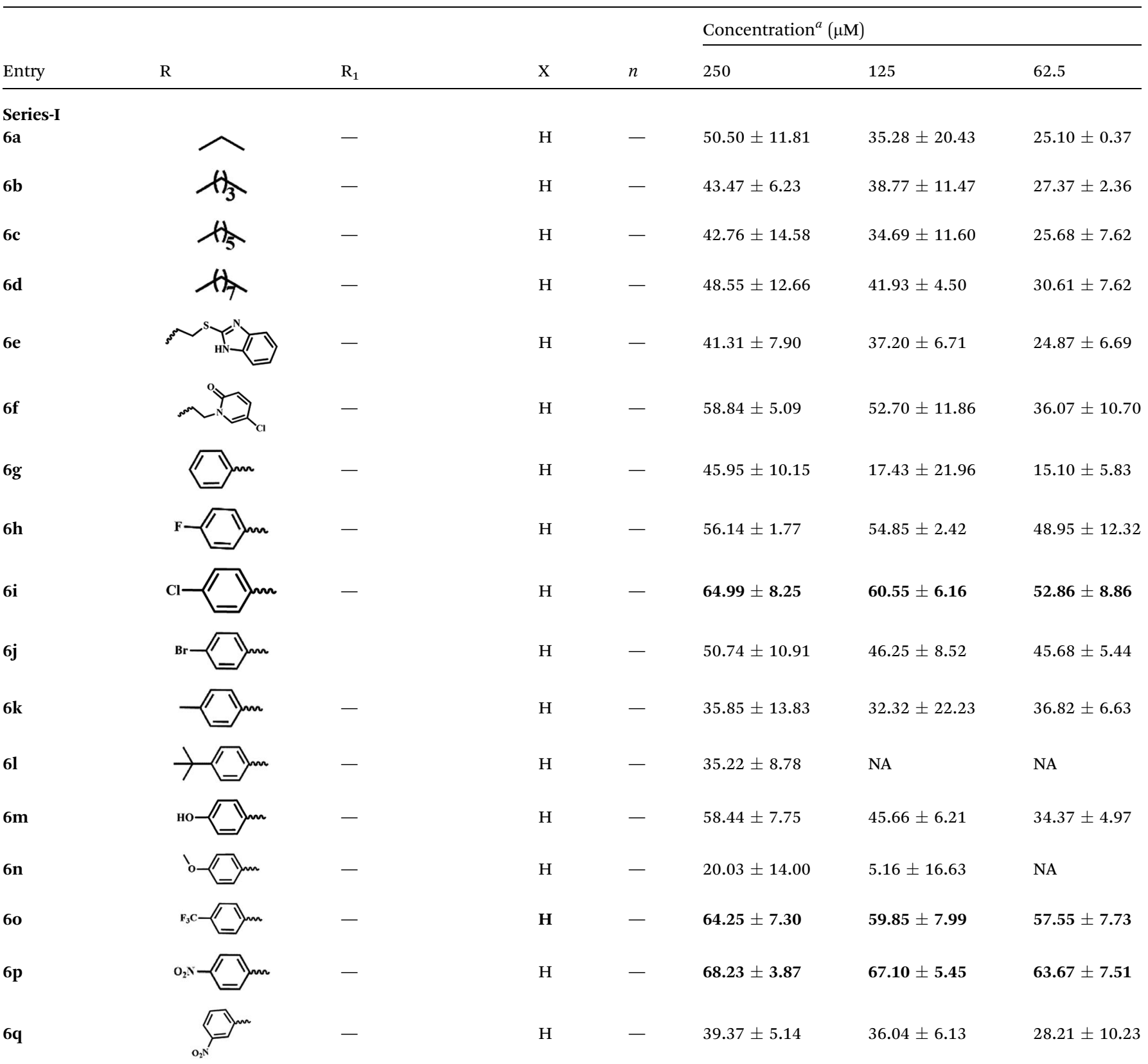

\section{Series-II}

$7 a$

$7 \mathbf{b}$<smiles>CCCCC</smiles>

$\mathrm{CH}_{3}$

$31.76 \pm 10.99$

$22.05 \pm 14.66$

$19.85 \pm 3.80$

$\begin{array}{lll}\mathrm{CH}_{3} & - & 26.59 \pm 20.80\end{array}$

$20.22 \pm 11.52$

$16.92 \pm 5.74$

$7 c$<smiles>[13CH2]</smiles>

$\mathrm{CH}_{3}$

NA

NA

NA

$7 d$

1)

$\begin{array}{lll}\mathrm{CH}_{3} & - & 44.57 \pm 3.87\end{array}$

$41.65 \pm 5.08$

$37.11 \pm 7.75$

$7 e$<smiles>CCCSc1nc(C)c(C)[nH]1</smiles>

$\mathrm{CH}_{3}$

$-\quad 16.00 \pm 26.10$

NA

$15.13 \pm 9.82$

$7 f$<smiles>CCCN(C=C1C=CC(Cl)=CC1=O)CC</smiles>

$\mathrm{CH}_{3}$

$-\quad 36.80 \pm 7.90$

$29.03 \pm 13.57$

$26.08 \pm 7.69$ 
Table 2 (Contd.)

\begin{tabular}{|c|c|c|c|c|c|c|c|}
\hline \multirow[b]{2}{*}{ Entry } & \multirow[b]{2}{*}{$\mathrm{R}$} & \multirow[b]{2}{*}{$\mathrm{R}_{1}$} & \multirow[b]{2}{*}{$\mathrm{X}$} & \multirow[b]{2}{*}{$n$} & \multicolumn{3}{|c|}{ Concentration $^{a}(\mu \mathrm{M})$} \\
\hline & & & & & 250 & 125 & 62.5 \\
\hline $7 \mathrm{~g}$ & & - & $\mathrm{CH}_{3}$ & - & $47.56 \pm 14.43$ & $29.85 \pm 17.40$ & $28.51 \pm 8.41$ \\
\hline $7 \mathbf{h}$ & & - & $\mathrm{CH}_{3}$ & - & $57.60 \pm 7.43$ & $44.67 \pm 14.27$ & $31.23 \pm 5.02$ \\
\hline $7 \mathbf{i}$ & & - & $\mathrm{CH}_{3}$ & - & $50.74 \pm 12.31$ & $14.91 \pm 8.82$ & NA \\
\hline $7 \mathbf{j}$ & $\mathrm{HO}$ & - & $\mathrm{CH}_{3}$ & - & $44.73 \pm 13.15$ & $24.16 \pm 14.52$ & $17.62 \pm 6.21$ \\
\hline $7 \mathrm{~m}$ & & - & $\mathrm{CH}_{3}$ & - & $53.85 \pm 9.78$ & $31.46 \pm 16.18$ & $21.02 \pm 10.29$ \\
\hline $7 \mathbf{n}$ & & - & $\mathrm{CH}_{3}$ & - & $46.73 \pm 4.87$ & $34.42 \pm 14.10$ & $34.20 \pm 7.43$ \\
\hline
\end{tabular}

\section{Series-III}

10a
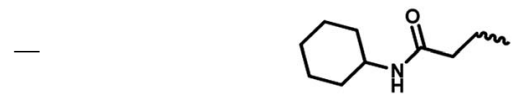

$\mathrm{H}$

1

$47.40 \pm 2.69$

$42.35 \pm 8.46$

$38.43 \pm 7.72$

10b

$-$<smiles>CCCC(=O)Nc1ccccn1</smiles>

$\mathrm{H}$

1

$28.46 \pm 17.54$

$15.64 \pm 7.17$

$4.40 \pm 2.93$

11a
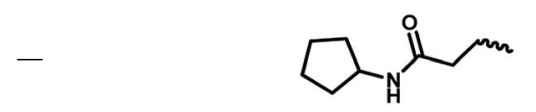

$\begin{array}{lll}\mathrm{H} & 2 & 51.23 \pm 7.10\end{array}$

$45.93 \pm 8.18$

$42.27 \pm 10.29$

$11 b$

$-$<smiles>CCCC(=O)NC1CCCCC1</smiles>

$\mathrm{H}$

2

$12.87 \pm 20.18$

NA

NA

11c<smiles>CCCC(=O)Nc1ccccn1</smiles>

$\mathrm{H}$

2

$19.41 \pm 8.16$

$15.69 \pm 8.81$

$3.69 \pm 11.15$

11d

-<smiles>C[C+]1C=CC(=[N+]([O-])[O-])C1</smiles>

H

2

$39.38 \pm 4.60$

$21.37 \pm 2.62$

$21.17 \pm 1.76$

12a

12b<smiles>CCCC(=O)NC1CCCC1</smiles>

$\mathrm{CH}_{3} \quad 2$

$48.48 \pm 5.25$

$34.14 \pm 12.60$

$28.54 \pm 7.69$<smiles>CCCC(=O)Nc1ccccn1</smiles>

$\mathrm{CH}_{3} \quad 2$

$30.83 \pm 26.38$

$9.74 \pm 20.67$

$5.35 \pm 10.20$

$12 c$

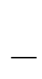

$\mathrm{CH}_{3} \quad 2$

$48.26 \pm 13.42$

$7.07 \pm 11.80$

NA

Furanone 30 -

$83.02 \pm 3.15$

$77.33 \pm 2.00$

${ }^{a}$ Growth inhibition, \pm standard deviation of the mean from at least two independent experiments. In each independent experiment, compounds were tested in triplicate. NA: no activity. 
MTT Assay HEK 24h
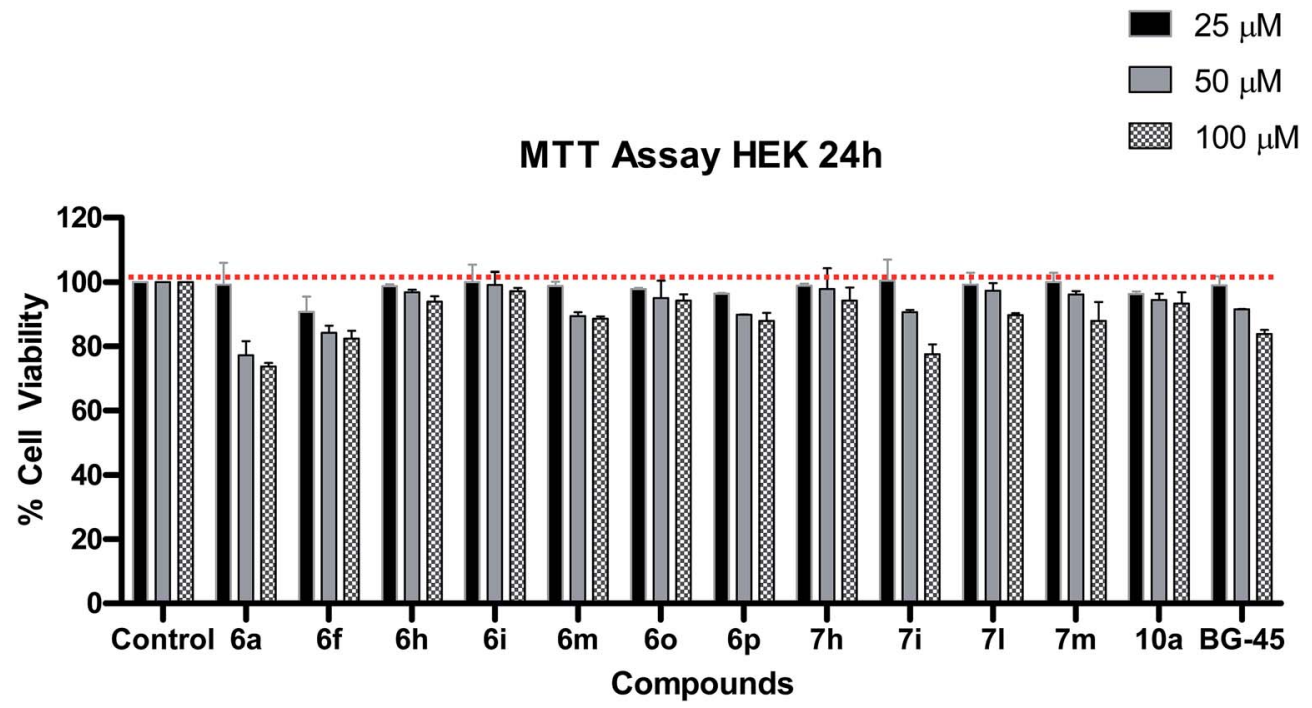

Fig. 4 Cytotoxicity study of the most active QSIs in HEK-293 cells by MTT assay after $24 \mathrm{~h}$ compound treatment. BG45 was used as a positive control. Data represents mean $\pm \mathrm{SD}(n=3)$.

Benzimidazoles $\mathbf{6 m}$ with a phenol group present on the triazole nucleus possesses moderate QSI activity at low concentrations $(34.37 \%$ at $62.5 \mu \mathrm{M})$, however, when the phenol group was substituted by a different electron-releasing anisole group (6n), the QSI activity of the molecule was completely abolished. This suggested that QSI activity of a compound could not be correlated by attaching an electron-releasing group at the paraposition of the phenyl ring on the triazole nucleus. Following this finding, the effect of substituting electron withdrawing groups on the aryl ring towards QS inhibition was studied. Benzimidazole compound $\mathbf{6 0}$ bearing a trifluoromethyl group on the aryl ring exhibited a significantly higher QSI activity $(57.55 \%$ inhibition at $62.5 \mu \mathrm{M})$ when compared to its parent compound $6 \mathrm{~g}$ (with only $15.10 \%$ inhibition at $62.5 \mu \mathrm{M}$ ) and the QSI activity is further enhanced by substituting more electronwithdrawing nitro group at para-position of the phenyl ring, with compound $6 \mathrm{p}$ showed $63.67 \%$ inhibition at $62.5 \mu \mathrm{M}$. However, when the nitro group was moved to the meta-position (6q), QSI activity was diminished $(28.21 \%$ at $62.5 \mu \mathrm{M})$. From the QSI data of this series, it can be concluded that, QSI activity of the benzimidazole molecule is favored by the presence of aryl ring with a para-substituted electron-withdrawing group on the triazole nucleus.

In the second part of the series (Series-II), benzimidazoles 7a-n bearing di-methyl substitution on the benzene ring was considered as basic moiety and the effect of substitution on the triazole nucleus towards the QSI activity was investigated. When alkyl groups of different lengths were placed on the triazole nucleus, dimethylbenzimidazole (compound 7d) with the longest carbon chain exhibited moderate activity $(44.57 \%$ at $250 \mu \mathrm{M})$. The QSI activity of the compounds reduced while decreasing the alkyl chain length. When introducing heterocyclic groups such as 2methylthio-benzimidazole (7e) and 5-chloro-pyridone (7f) onto the triazole nucleus, the analogues only showed mild inhibitory activity even at the highest tested concentration. In another attempt, various aryl groups bearing different substituents on triazole nucleus were investigated. The presence of an electrondonating methyl group at the 4-position of the aryl ring (7i) did not impact the inhibitory activity at higher doses $(50.74 \%$ at 250 $\mu \mathrm{M}$ ) when compared to its un-substituted parent molecule $\mathbf{7 g}$, in fact, it hampered the QSI inhibition at lower concentrations. The presence of other electron-donating groups such as hydroxyl $(7 \mathbf{j})$ and alkoxy (7k) at the 4-position of the phenyl ring were also found to be effective only at higher concentrations ( $>40 \%$ at $250 \mu \mathrm{M}$ ). In case of aryl rings possessing electron withdrawing groups, trifluoromethyl group at para-position enhanced the QSI activity of the dimethylbenzimidazole $(65.80 \%$ at $250 \mu \mathrm{M})$, while other nitro substituted aryl partners were effective only at higher concentrations $(\mathbf{7 m} \& \mathbf{7 n})$. It can be concluded that aryl substituted triazole nucleus based dimethylbenzimidazole derivatives displayed better QS inhibition activity when electron withdrawing groups are present on the aryl ring.

Apart from the above moieties studied so far, few more 2aminobenzimidazole derivatives were designed and synthesized by altering the length of carbon chain between the amido functional group and the triazole moiety as well as placing different functionalities on triazole nucleus (SeriesIII). All these moieties were explored for their QSI at reported concentrations. In the first part of this series, the chain length between the 2-amido benzimidazole and the triazole nucleus was fixed at two and two analogues 10a and $10 \mathrm{~b}$ were synthesized by retaining different substitutions on the triazole nucleus. Among these, $N$-cyclohexyl acetamido substitution at the triazole (10a) showed good QSI activity regardless of the concentration $(38-47 \%$ at $62.5-250 \mu \mathrm{M})$. In the later series, the length of the carbon chain between the 2amido benzimidazole and the triazole nucleus was increased to three. Four benzimidazoles (11a-d) with the three carbon chain length were synthesized and tested for their QSI activity. It was found that triazole carrying $\mathrm{N}$-cyclopentyl 
Table 3 In silico predicted physico-chemical and pharmacokinetic parameters of the titled compounds

\begin{tabular}{|c|c|c|c|c|c|c|c|c|c|}
\hline Entry & Mol. wt ${ }^{a}$ & SASA $^{b}$ & $\mathrm{HBD}^{c}$ & $\mathrm{HBA}^{d}$ & $\log \mathrm{Po} / \mathrm{w}^{e}$ & $\mathrm{PCaco}^{f}$ & $\log \mathrm{BB}^{g}$ & $\log S^{h}$ & Rot. bonds ${ }^{i}$ \\
\hline $6 a$ & 284.32 & 567.436 & 0 & 3.5 & 3.038 & 343.769 & -1.286 & -4.161 & 6 \\
\hline $6 b$ & 312.374 & 636.971 & 0 & 3.5 & 3.92 & 429.085 & -1.412 & -5.153 & 8 \\
\hline 6d & 368.481 & 743.435 & 0 & 3.5 & 5.268 & 305.705 & -1.907 & -6.519 & 12 \\
\hline $6 e$ & 404.448 & 584.577 & 1 & 5.0 & 3.838 & 605.209 & -0.839 & -4.174 & 7 \\
\hline $6 f$ & 383.796 & 530.836 & 0 & 6.5 & 2.171 & 267.446 & -0.934 & -2.154 & 6 \\
\hline $6 i$ & 352.782 & 586.704 & 0 & 3.5 & 3.94 & 351.095 & -0.933 & -5.163 & 4 \\
\hline $6 j$ & 397.233 & 589.559 & 0 & 3.5 & 4.025 & 354.108 & -0.911 & -5.242 & 4 \\
\hline $6 k$ & 332.364 & 594.968 & 0 & 3.5 & 3.794 & 375.045 & -1.088 & -5.008 & 4 \\
\hline 61 & 374.444 & 636.388 & 0 & 3.5 & 4.559 & 358.01 & -1.138 & -5.63 & 5 \\
\hline $6 \mathrm{~m}$ & 334.337 & 570.734 & 1 & 4.25 & 2.794 & 106.664 & -1.634 & -4.336 & 5 \\
\hline $6 n$ & 348.363 & 629.418 & 0 & 4.25 & 3.834 & 519.109 & -1.094 & -5.105 & 5 \\
\hline $7 \mathbf{b}$ & 340.427 & 671.361 & 0 & 3.5 & 4.387 & 413.083 & -1.414 & -5.715 & 8 \\
\hline $7 c$ & 368.481 & 753.598 & 0 & 3.5 & 5.352 & 506.822 & -1.573 & -7.037 & 10 \\
\hline $7 d$ & 396.534 & 826.137 & 0 & 3.5 & 6.173 & 496.042 & -1.803 & -8.086 & 12 \\
\hline $7 e$ & 432.502 & 774.439 & 1 & 5.0 & 4.777 & 146.42 & -1.994 & -7.549 & 7 \\
\hline $7 f$ & 411.85 & 546.498 & 0 & 6.5 & 2.611 & 358.622 & -0.82 & -2.398 & 6 \\
\hline $7 \mathrm{~g}$ & 346.391 & 593.336 & 0 & 3.5 & 3.9 & 361.81 & -1.048 & -4.977 & 4 \\
\hline $7 \mathbf{h}$ & 425.287 & 623.302 & 0 & 3.5 & 4.458 & 341.091 & -0.935 & -5.879 & 4 \\
\hline $7 \mathbf{i}$ & 360.418 & 620.804 & 0 & 3.5 & 4.176 & 339.567 & -1.108 & -5.498 & 4 \\
\hline $7 \mathbf{j}$ & 362.39 & 591.857 & 1 & 4.25 & 3.165 & 104.014 & -1.59 & -4.71 & 5 \\
\hline $7 \mathbf{k}$ & 376.417 & 617.631 & 0 & 4.25 & 4.029 & 420.983 & -1.026 & -4.882 & 5 \\
\hline 71 & 414.389 & 700.508 & 0 & 3.5 & 5.396 & 514.904 & -0.833 & -7.521 & 4 \\
\hline $7 m$ & 391.388 & 639.666 & 0 & 4.5 & 3.217 & 43.007 & -2.11 & -5.169 & 5 \\
\hline $12 b$ & 437.544 & 842.109 & 2 & 8.0 & 3.317 & 87.762 & -2.177 & -6.169 & 8 \\
\hline $12 \mathrm{c}$ & 432.484 & 835.341 & 2 & 9.0 & 3.272 & 107.993 & -2.472 & -6.752 & 8 \\
\hline
\end{tabular}

${ }^{a}$ Mol. wt - molecular weight (130-725). ${ }^{b}$ SASA - solvent accessible surface area (300-1000). ${ }^{c}$ HBD - no. of hydrogen bond donors $(0-6) .{ }^{d}$ HBA - no. of hydrogen bond acceptors ( 2 to 20$).{ }^{e} \log$ Po/w - predicted octanol/water partition coefficient $(-2.0-6.5) \cdot{ }^{f}$ Caco -2 cell permeability in nm s ${ }^{-1}(<25$ poor, $>500$ great). ${ }^{g} \log \mathrm{BB}$ - predicted brain/blood partition coefficient $(-3.0-1.2) .{ }^{h} \log \mathrm{S}-$ aqueous solubility of a compound $\left(-6.5-0.5 \mathrm{~mol} \mathrm{dm}{ }^{-3}\right)$. Rot - no. of rotatable bonds ( 0 to 15 ).

acetamido group (11a) was identified to be the most potent compound in this series and its potency was retained even at lower concentration $(42.27 \%$ at $62.5 \mu \mathrm{M})$. On the other end, compound 11d with 4-nitrophenyl group on triazole nucleus was active only at high doses $(39.38 \%$ at $250 \mu \mathrm{M})$. The remaining analogues $\mathbf{1 1 b}$-c were less potent even at highest tested concentration. Finally, by maintaining three carbon chain length, various dimethylbenzimidazoles were also investigated. Dimethylbenzimidazoles possessing $\mathrm{N}$-(2pyridyl)-acetamido group on triazole nucleus (12c) showed moderate inhibition activity only at high concentration $(48.26 \%$ at $250 \mu \mathrm{M})$ and its inhibition activity was diminished when its concentration was halved. The same trend was observed for compound 12b with a $N$-cyclohexyl acetamido group placed at the triazole nucleus. On the other hand, compound 12a exhibited moderate inhibition activity at 250 $\mu \mathrm{M}$. While its inhibition activity reduces with the decrease in concentration, the magnitude of the reduction was smaller than that of compounds $\mathbf{1 2 b}$-c. It can be concluded that $\mathrm{N}-(2-$ pyridyl), $N$-cyclopentyl and $N$-cyclohexyl acetamido substituted triazoles exhibited moderate QSI activity at high concentration within this series.

Overall, it can be concluded that, most of the scaffolds in this study possess moderate to high inhibition activity at high concentration and compounds $\mathbf{6 i}, \mathbf{6 0}, \mathbf{6 p}$ and $7 \mathbf{l}$ exhibited significant QSI activity at all the reported concentrations and were 


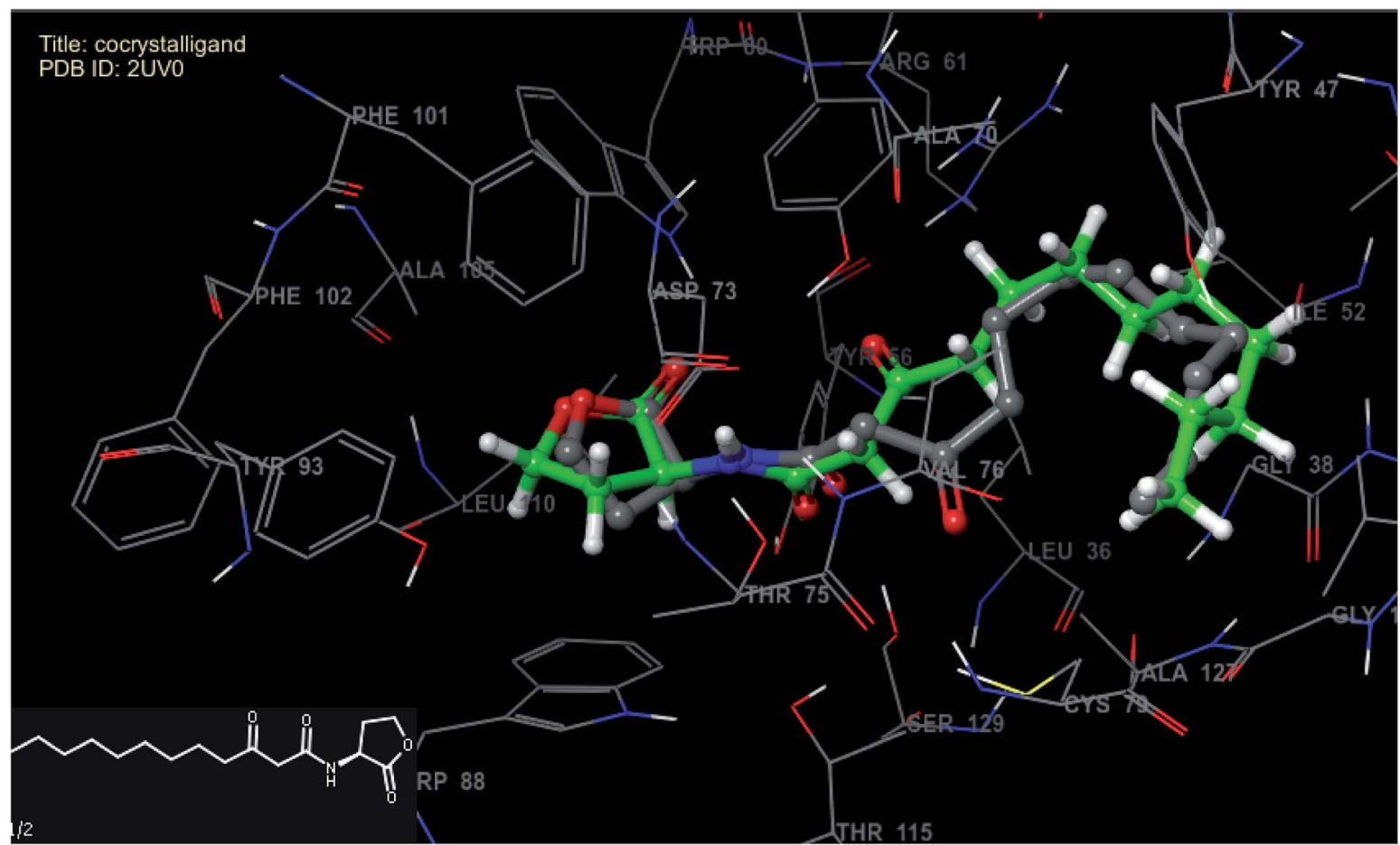

Fig. 5 Superimposed view of best scoring native pose of co-crystallized (grey) ligand with its X-ray pose (green) inside the active site of $2 U V 0$.

identified to be the most active compounds in this study. Most of the compounds reported in the current work exhibited comparable activity to the previously reported triazoles as shown in Table 2 . The most active compound from this study, $\mathbf{6 p}$ is better than the previously reported compounds ( $\mathbf{V}-\mathbf{I X}$ of Table 1$)$.

\section{Cytotoxicity studies}

On the basis of QS inhibitory activity, the significantly active compounds (6a, 6f, 6h, 6i, 6m, 6o, 6p, 7h, 7i, 7l, 7m and 10a) were evaluated for their cytotoxicity against Human Embryonic Kidney cell lines (HEK-293) at 25, 50 and $100 \mu \mathrm{M}$

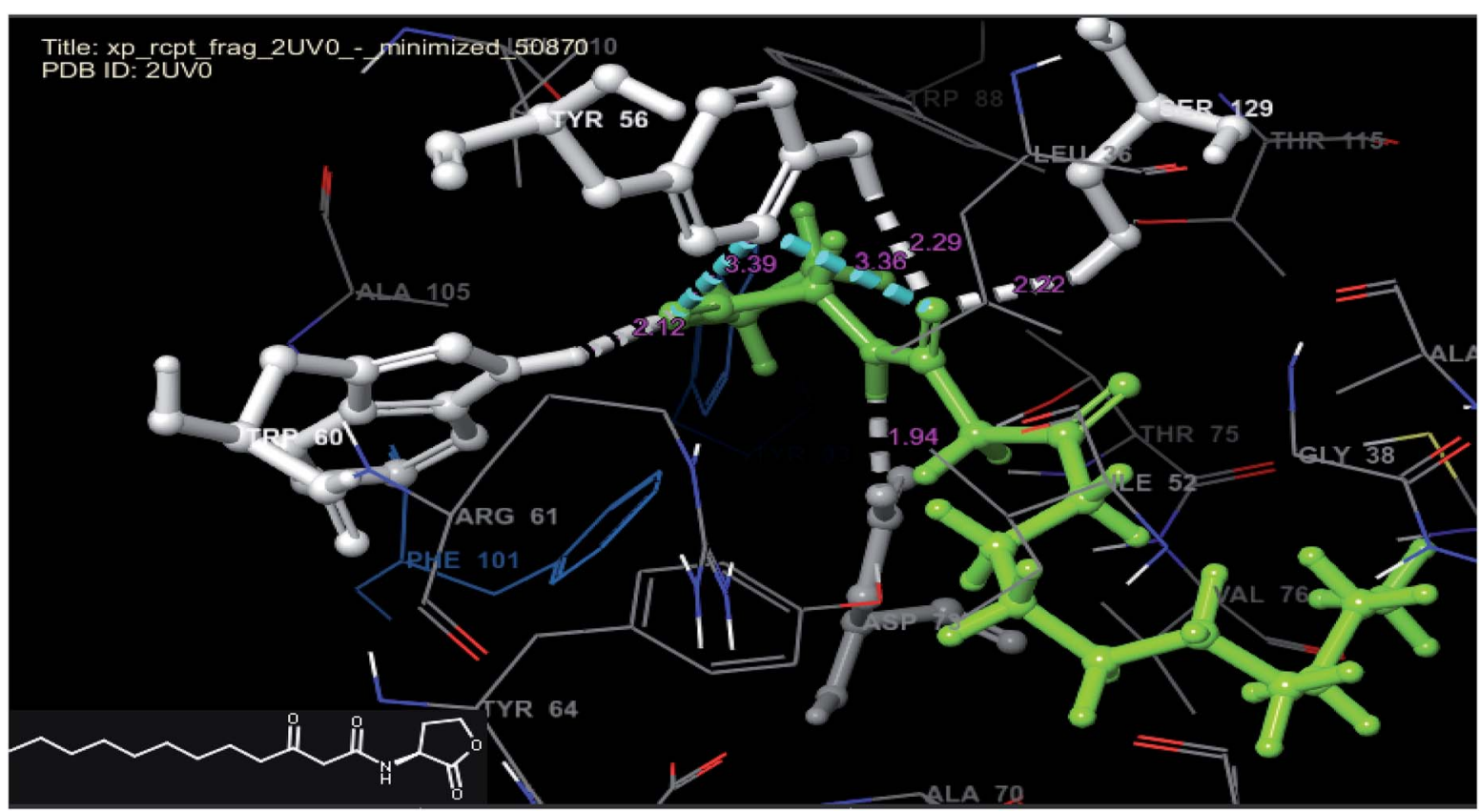

Fig. 6 Docked pose view of co-crystallized ligand with interactions and distances (color interpretation: white-hydrogen bond, blue pi-pi stacking) inside the active site of 2 UVO. 


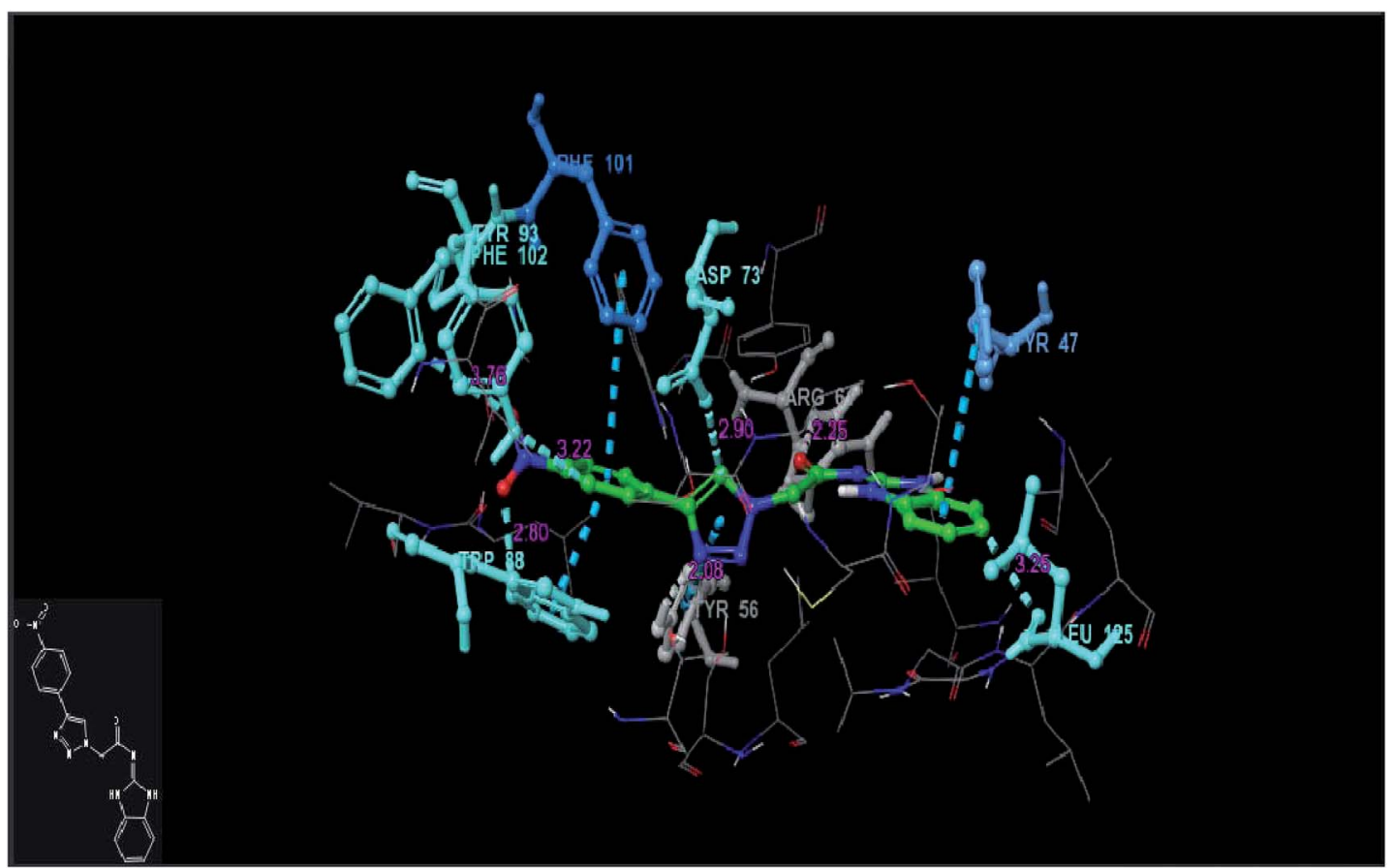

Fig. 7 Docked pose view of compound $6 \mathrm{p}$ inside the 2 UVO, showing interactions and distances (color interpretation: white-hydrogen bond, blue pi-pi stacking).

concentrations using BG45 as a positive control. Most of the compounds have low cytotoxicity at all tested concentrations using MTT assay (Fig. 4). ${ }^{38}$

\section{In silico prediction of drug likeness properties}

Physicochemical parameters of the designed compounds were in silico predicted using Qik-prop module of Schrödinger. ${ }^{39,40}$ The in silico predicted values of physico-chemical parameters

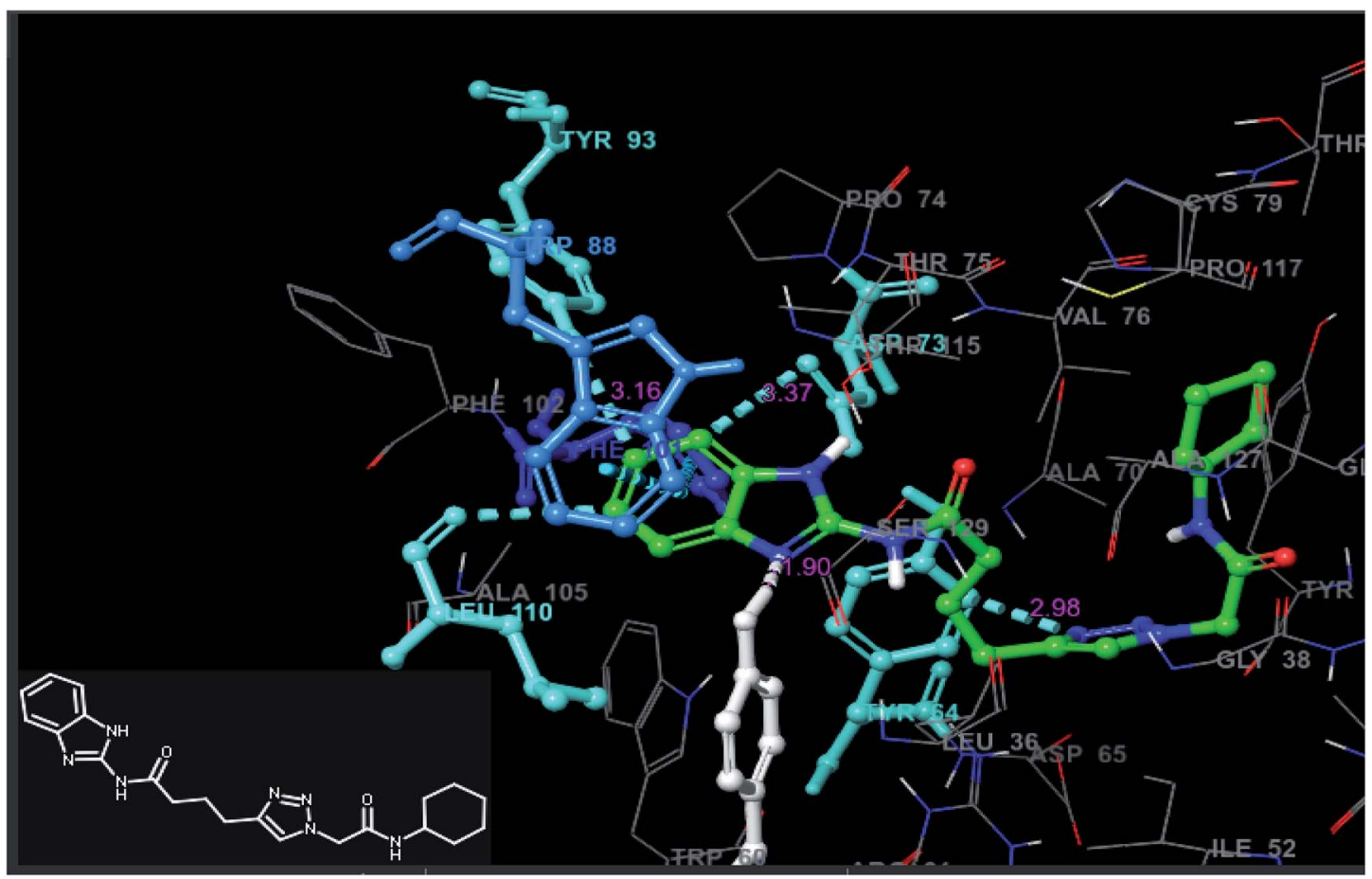

Fig. 8 Docked pose view of compound 11b inside the 2UV0, showing interactions and distances (color interpretation: white-hydrogen bond, blue pi-pi stacking). 
Table 4 Crystal data and structure refinement for $6 d$

\section{Identification code}

Empirical formula

Formula weight

Temperature/K

Crystal system

Space group

$a / \AA$

$b / \AA$

$c / \AA$

$\alpha /^{\circ}$

$\beta /^{\circ}$

$\gamma /^{\circ}$

Volume $/ \AA^{3}$

$Z$

$\rho_{\text {calc }} \mathrm{g} / \mathrm{cm}^{3}$

$\mu / \mathrm{mm}^{-1}$

$F(000)$

Crystal size $/ \mathrm{mm}^{3}$

Radiation

$2 \Theta$ range for data collection $/^{\circ}$

Index ranges

Reflections collected

Independent reflections

Data/restraints/parameters

Goodness-of-fit on $F^{2}$

Final $R$ indexes $[I \geq 2 \sigma(I)]$

Final $R$ indexes [all data]

Largest diff. peak/hole/e $\AA^{-3}$

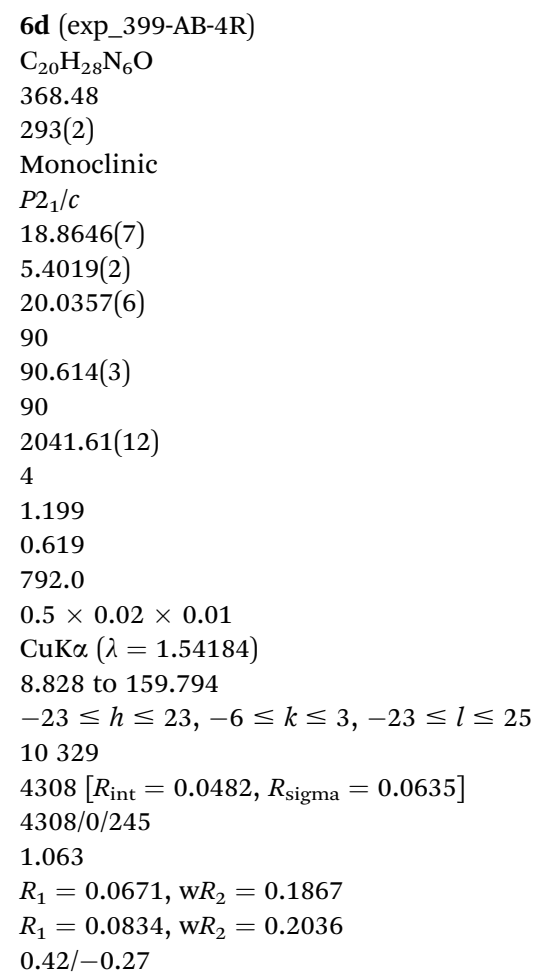

for the titled compounds ( $\mathbf{6 a}-\mathbf{q}, \mathbf{7 a - n}, \mathbf{1 0 a}-\mathbf{b}, \mathbf{1 1 a}-\mathbf{d}, \mathbf{1 2 a}-\mathbf{c})$ were shown in Table 3. Furthermore, ranges of these parameters followed by $95 \%$ of market approved drugs are given as footnotes of Table 3 (ref. 41 and 42) for comparison.

The predicted values of these parameters revealed that all the parameters like mol. wt., hydrogen bond donors (HBD), hydrogen bond acceptors (HBA), solvent accessible surface area (SASA), partition co-efficient (log P), predicted apparent Caco-2
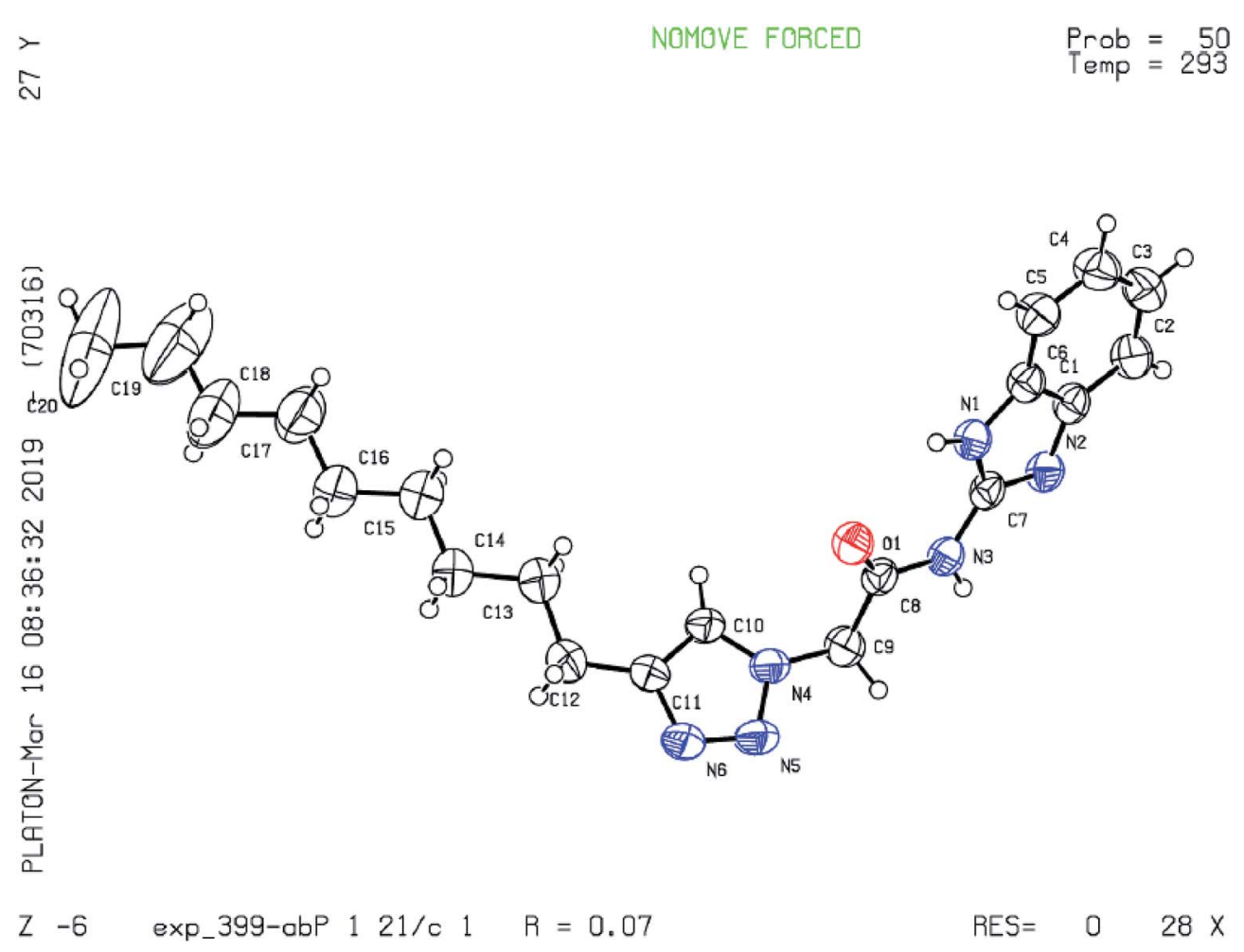

Fig. 9 ORTEP crystal structure diagram of compound. 
cell permeability (PCaco), predicted brain/blood partition coefficient $(\log \mathrm{BB})$, aqueous solubility $(\log S)$ and number of rotatable bonds (Rot) were found within acceptable range and followed Lipinski rule of five. So overall, based upon the predicted values of these physico-chemical parameters, all the titled compounds possessed the drug-likeness behavior.

\section{Docking studies}

We performed molecular docking to investigate the binding mode of most active QSI $\mathbf{6 p}$ with LasR receptor by the X-ray structure (PDB ID: 2UV0). For the docking study, we selected co-crystal structure as the source of the target taken is from the organism $P$. aeruginosa LasR and its resolution is better compared to other available PDB structures. Moreover, all the titled compounds were screened against the strain of $P$. aeruginosa and hence we took the same species for docking to get better correlation.

Docking studies of the significantly active compound (6p) and least active compound (11b) was performed using Glide 5.9 (ref. 43) running on maestro version 9.4, to investigate their putative binding mode with the target protein. Enzyme used for the docking study was LasR receptor protein (PDB: 2UV0) of $P$. aeruginosa, retrieved from RCSB, Protein Data Bank. ${ }^{44}$ Protein preparation wizard of Schrödinger suite was used for preparation of target protein.

In order to predict the nature of binding mode of significant and least active compounds ( $\mathbf{6 p}$ and $\mathbf{1 1 b}$ respectively) with the target protein, docking studies were carried out. The value of RMSD obtained between X-ray pose and re-docked pose (Fig. 5) for co-crystallized ligand in target protein was found to be 1.55 $\AA$, suggesting that docking protocol could be relied on for the docking studies. The best docked pose (docking score -8.62) view of the co-crystallized ligand inside the active site of the target protein (PDB ID: 2UV0) is shown in Fig. 6. The figure revealed that, the co-crystallized ligand exhibited four hydrogen bond interactions with TYR 56 (2.29 $)$ ), TRP 60 (2.12 A), ASP 73 (1.94 $\AA$ ) and SER $129(2.22 \AA)$ amino acid residues of the protein and two pi-pi stacking interactions (3.39 and $3.36 \AA$ ) respectively.

The analysis of best docked pose (Fig. 7) of compound $\mathbf{6 p}$ (docking score -8.40 ) revealed that, the compound showed hydrogen bond interaction with TYR 56 (2.08 ̊) and ASP 73 $\left(\begin{array}{ll}2.90 \AA\end{array}\right)$ as that of co-crystallized ligand and also formed hydrogen bond interactions with ARG 61 (2.25 ̊), TYR-93 (3.76

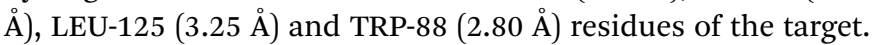
The compound also exhibited three pi-pi stacking interactions with TYR-47 (2.25 ̊), TRP-88 (2.80 A) and PHE-101 (3.22 A) residues of the target protein and hence might stabilize its binding affinity with the target receptor, consequently may be responsible for its significant in vitro activity. The best docked pose (Fig. 8) of compound 11b (docking score -9.06) displayed weak hydrogen bond interactions between TYR-64 (2.96 ̊), TYR$93(1.90 \AA)$ and ASP $73(3.37 \AA)$ residues of target protein. The compound also exhibited pi-pi stacking interactions with Trp88 (3.16 ̊) residues. This weak binding affinity of compound 11b may be responsible for its lower activity in the in vitro assay.

\section{Single crystal X-ray crystallographic structure of compound $6 \mathrm{~d}$}

The suitable crystals of the compound $\mathbf{6 d}$ for X-ray crystallographic study were grown from the mixture of methanol and dichloromethane $(1: 1)$ solution. The single crystal X-ray diffraction measurement of the molecule $\left(\mathrm{C}_{20} \mathrm{H}_{28} \mathrm{~N}_{6} \mathrm{O}\right)$ was on Rigaku XtaLAB P200 diffract meter using graphite monochromated Cu-Ka radiation $(\lambda=1.54184 \AA)$ on $0.5 \mathrm{~mm} \times$ $0.02 \mathrm{~mm} \times 0.01 \mathrm{~mm}$ colorless crystal. Data were collected and processed using CrysAlisPro (Rigaku Oxford Diffraction). The data were collected at a temperature of $293 \mathrm{~K}$ to a maximum $2 q$ value of $159.794^{\circ}$. Of the 10329 reflections were collected, where 4308 were unique $\left(R_{\text {int }}=0.0482\right)$ and equivalent reflections were merged. The crystal was kept at 293(2) K during data collection. Using Olex2, the structure was solved with the ShelX structure solution program using Direct Methods and refined with the ShelXL refinement package using least squares minimization. The basic crystallographic data are shown in Table 4 . The molecular structure of the compound with methanol and dichloromethane solvents of crystallization is given as an ORTEP diagram in Fig. 9. The chain of nine carbons with $\mathrm{C} 12$ is directly bonded to $\mathrm{C} 11$ with more rigidity. As we move from $\mathrm{C} 12$ to $\mathrm{C} 20$, since the molecule is continuously undergoing vibration the terminal C20 with more flexibility experiences higher degree of vibrations as compare to $\mathrm{C12}$. Therefore, the thermal parameters increase as we go from $\mathrm{C} 12$ to $\mathrm{C} 20$ and it is highest for C20. Crystallographic data for the compound $\mathbf{6 d}$ have been deposited to the Cambridge Crystallographic Data Center and corresponding deposition number is CCDC 1904042.

\section{Conclusion}

In conclusion, series of novel 1,2,3-triazole derivatives of 2aminobenzimidazole and 2-amino-5,6-dimethylbenzimidazole were designed and synthesized. All synthesized compounds were characterised using ${ }^{1} \mathrm{H} \mathrm{NMR},{ }^{13} \mathrm{C}$ NMR, mass spectrometry and elemental analyses. The QSI activity of all 40 final compounds was evaluated against $P$. aeruginosa MH602. Among all derivatives, three compounds, 6i, 6o, 6p and $7 \mathbf{l}$ exhibited promising QSI activity of 64.99, 64.25, 68.23 and $65.80 \%$ against $P$. aeruginosa MH602 at $250 \mu \mathrm{M}$, respectively. These three compounds also exhibited significant activity at low concentrations (125 and $62.5 \mu \mathrm{M}$ ). Like, previously reported triazole based AHL analogues (III and IV), 6p exhibited greatest QSI activity at low concentrations with $63.67 \%$ inhibition at 62.5 $\mu \mathrm{M}$. These compounds were not found to be toxic when treated in normal cell line (HEK cell line) at 25, 50 and $100 \mu \mathrm{M}$. Hence, these compounds may become good starting point for further refinement in order to emerge as potent molecules with maximum therapeutic effect.

\section{Experimental section}

\section{Materials and methods}

All chemical reagents and solvents are purchased from Aldrich, Alfa Aesar, Finar. The solvents and reagents were of LR grade. All the solvents were dried and distilled before use. Thin-layer 
chromatography (TLC) was carried out on aluminiumsupported silica gel plates (Merck 60 F254) with visualization of components by UV light (254 nm). Column chromatography was carried out on silica gel (Merck 100-200 mesh). ${ }^{1} \mathrm{H}$ NMR and ${ }^{13} \mathrm{C}$ NMR spectra were recorded at $400 \mathrm{MHz}$ and $101 \mathrm{MHz}$ respectively using a Bruker AV 400 spectrometer (Bruker CO., Switzerland) in $\mathrm{CDCl}_{3}$ and DMSO- $d_{6}$ solution with tetramethylsilane as the internal standard and chemical shift values $(\delta)$ were given in ppm. ${ }^{1} \mathrm{H}$ NMR spectra were recorded in $\mathrm{CDCl}_{3}$ or DMSO- $d_{6}$. The following abbreviations are used to designate multiplicities: $\mathrm{s}=$ singlet, $\mathrm{d}=$ doublet, $\mathrm{t}=$ triplet, $\mathrm{m}=$ multiplet, $\mathrm{br}=$ broad. Melting points were determined on an electro thermal melting point apparatus (Stuart-SMP30) in open capillary tubes and are uncorrected. Elemental analyses were performed by Elementar Analysensysteme GmbH vario MICRO cube CHN Analyzer. Mass spectra (ESI-MS) were recorded on Schimadzu MS/ESI mass spectrometer.

\section{General synthetic procedure for compounds $6 a-q$ and $7 a-n$}

A solution of azide (5a) $(0.5 \mathrm{~g}, 2.3 \mathrm{mmol})$ in DMF : $\mathrm{H}_{2} \mathrm{O}(8: 2)$ was reacted with various substituted acetylenes $(0.24 \mathrm{~g}, 3.5$ $\mathrm{mmol})$ in the presence of sodium ascorbate $(0.023 \mathrm{~g}$, $5 \mathrm{~mol} \%), \mathrm{CuSO}_{4} \cdot 5 \mathrm{H}_{2} \mathrm{O}(0.006 \mathrm{~g}, 1 \mathrm{~mol} \%)$. The reaction mixture was stirred at $\mathrm{rt}$ for $6-24 \mathrm{~h}$. The reaction mixture was monitored by TLC. Upon completion of the reaction, as indicated by TLC, the reaction was diluted with ethyl acetate and washed with water. Organic layer was dried over anhydrous sodium sulphate, concentrated under reduced pressure and the crude residue was purified by column chromatography using 60-90\% ethyl acetate in hexane as eluent to give $0.57 \mathrm{~g}$ of the title compound $N$ - $(1 H$-benzo[ $d]$ imidazol-2-yl)-2-(4-propyl-1H-1,2,3-triazol-1-yl)acetamide (6a) (yield: $88 \%$ ). Similar procedure was followed to get the compounds $\mathbf{6 b}-\mathbf{q}$ and $7 \mathbf{a}-\mathbf{n}$ from $\mathbf{5 a}$ and $\mathbf{5 b}$ respectively.

\section{General synthetic procedure for $9 a-c$}

To a solution of compound (2a) (0.5 g, $3.776 \mathrm{mmol})$ in DMF (8.0 $\mathrm{mL}$ ) at $0{ }^{\circ} \mathrm{C}$ was added EDC- $\mathrm{HCl}(1.08 \mathrm{~g}, 5.64 \mathrm{mmol})$, diisopropyl ethylamine $(1.33 \mathrm{~mL}, 9.4 \mathrm{mmol})$, and HOBt (0.76 g, 5.664 $\mathrm{mmol}$ ). The reaction mixture was stirred at $\mathrm{rt}$ for $16 \mathrm{~h}$. Upon completion of the reaction, as indicated by TLC, DCM was added to the reaction mixture and washed with $10 \%$ bicarbonate and brine solution. The organic layer was dried over anhydrous $\mathrm{Na}_{2} \mathrm{SO}_{4}$ and concentrated in vacuo. The crude product was purified by column chromatography using $50-70 \%$ ethyl acetate in hexane as eluent to yield $0.66 \mathrm{~g}$ of $\mathrm{N}$ - $(1 \mathrm{H}$-benzo $[d]$ imidazol-2-yl)pent-4-ynamide (9a). Similar procedure was followed for preparation of 9a-c from 2a and $2 \mathbf{b}$. Yield: 9a: $82 \%$; 9b: $78 \%$ and 9c: $80 \%$ (pale brown solids).

\section{General synthetic procedure for $10 \mathrm{a}-\mathrm{c}, 11 \mathrm{a}-\mathrm{d}$ and $12 \mathrm{a}-\mathrm{c}$}

A solution of alkyne (9a) (0.5 g, $2.3 \mathrm{mmol})$ in DMF : $\mathrm{H}_{2} \mathrm{O}(8: 2)$ was reacted with 2-azido- $N$-cyclohexylacetamide (B) $(0.24 \mathrm{~g}, 2.34$ $\mathrm{mmol})$ in the presence of sodium ascorbate (0.023 $\mathrm{g}, 5 \mathrm{~mol} \%)$, $\mathrm{CuSO}_{4} \cdot 5 \mathrm{H}_{2} \mathrm{O}(0.006 \mathrm{~g}, 1 \mathrm{~mol} \%)$. The reaction mixture was stirred at $\mathrm{rt}$ for $12 \mathrm{~h}$. Upon completion of the reaction, as indicated by TLC, the reaction was diluted with ethyl acetate and washed with water. Organic layer was dried over anhydrous sodium sulphate, concentrated under reduced pressure and the crude residue was purified by column chromatography using $60-90 \%$ ethyl acetate in hexane as eluent to give $0.42 \mathrm{~g}$ of $N$ - $(1 H$-benzo[ $d]$ imidazol-2-yl)-3-(1-(2-(cyclohexylamino)-2-oxoethyl)-1H-1,2,3triazol-4-yl)propanamide (10a; yield 46\%). Similar procedure was followed in the synthesis of 10b, 11a-d and 12a-c from 9a, 9b and 9c respectively.

\section{Analytical data for the final compounds}

$\boldsymbol{N}$-(1H-Benzo[d]imidazol-2-yl)-2-(4-propyl-1H-1,2,3-triazol1-yl)acetamide (6a). Pale green; (88\%); m.p. 238-240 ${ }^{\circ} \mathrm{C}$; IR $\nu_{\max }\left(\mathrm{KBr}, \mathrm{cm}^{-1}\right) 3392,3124,2959,1637,1598 ;{ }^{1} \mathrm{H}$ NMR $(400$ MHz, DMSO) $\delta 12.05$ (s, 2H), $7.81(\mathrm{~s}, 1 \mathrm{H}), 7.33(\mathrm{dd}, J=5.9$, $3.2 \mathrm{~Hz}, 2 \mathrm{H}), 6.98(\mathrm{dd}, J=5.9,3.2 \mathrm{~Hz}, 2 \mathrm{H}), 5.27(\mathrm{~s}, 2 \mathrm{H}), 2.54(\mathrm{t}$, $2 \mathrm{H}), 1.54$ (sextet, $2 \mathrm{H}), 0.84$ (t, 3H). ${ }^{13} \mathrm{C}$ NMR (101 MHz, DMSO) $\delta 168.17$ 147.83, 147.04, 135.44, 124.02, 121.95, 114.13, 52.77, 27.47, 22.77, 14.0. ESI-MS: $(\mathrm{m} / \mathrm{z})$ calcd for $\mathrm{C}_{14} \mathrm{H}_{16} \mathrm{~N}_{6} \mathrm{O}: 284.32$, found $283.00(\mathrm{M}-\mathrm{H})^{+}$; anal. calcd for $\mathrm{C}_{14} \mathrm{H}_{16} \mathrm{~N}_{6} \mathrm{O}$ : (\%) C, 59.14; H, 5.67; N, 29.56; O, 5.63 found: C, 59.18; H, 5.63; N, 29.60; O, 5.59 .

$\mathrm{N}$-(1H-Benzo[d]imidazol-2-yl)-2-(4-pentyl-1H-1,2,3-triazol1-yl)acetamide (6b). Off white; (76\%); m.p. 224-226 ${ }^{\circ} \mathrm{C}$; IR $\nu_{\max }\left(\mathrm{KBr}, \mathrm{cm}^{-1}\right) 3386,3141,2957,1639,1592,1403 ;{ }^{1} \mathrm{H}$ NMR (400 MHz, DMSO) $\delta 12.13(\mathrm{~s}, 2 \mathrm{H}), 7.89$ (s, 1H), 7.43 (dd, $J=$ $5.9,3.2 \mathrm{~Hz}, 2 \mathrm{H}), 7.12(\mathrm{dd}, J=5.9,3.2 \mathrm{~Hz}, 2 \mathrm{H}), 5.36(\mathrm{~s}, 2 \mathrm{H})$, $2.64(\mathrm{t}, 2 \mathrm{H}), 1.72-1.52(\mathrm{~m}, 2 \mathrm{H}), 1.41-1.25(\mathrm{~m}, 4 \mathrm{H}), 0.88(\mathrm{t}, 3 \mathrm{H})$. ${ }^{13} \mathrm{C}$ NMR (101 MHz, DMSO) $\delta 168.15,147.81(\mathrm{~s}), 147.19$, 135.31, 123.89, 121.96, 114.12, 52.77, 31.22, 29.20, 25.39, 22.33, 14.36. ESI-MS: $(\mathrm{m} / \mathrm{z})$ calcd for $\mathrm{C}_{16} \mathrm{H}_{20} \mathrm{~N}_{6} \mathrm{O}: 312.37$, found $311.00(\mathrm{M}-\mathrm{H})^{+}$; anal. calcd for $\mathrm{C}_{16} \mathrm{H}_{20} \mathrm{~N}_{6} \mathrm{O}$ : (\%) C, 61.52; H, 6.45; N, 26.90; O, 5.12 found: C, 61.54; H, 6.43; N, 26.92; O, 5.10 .

$\mathrm{N}$-(1H-Benzo[d]imidazol-2-yl)-2-(4-heptyl-1H-1,2,3-triazol1-yl)acetamide (6c). White; (63\%); m.p. $218-220{ }^{\circ} \mathrm{C}$; IR $\nu_{\max }$ $\left(\mathrm{KBr}, \mathrm{cm}^{-1}\right) 3373,3144,2948,1632,1594,1401 ;{ }^{1} \mathrm{H}$ NMR (400 $\mathrm{MHz}, \mathrm{DMSO}) \delta 12.11(\mathrm{~s}, 2 \mathrm{H}), 7.84(\mathrm{~s}, 1 \mathrm{H}), 7.41(\mathrm{dd}, J=5.9$, $3.2 \mathrm{~Hz}, 2 \mathrm{H}), 7.032(\mathrm{dd}, J=5.9,3.2 \mathrm{~Hz}, 2 \mathrm{H}), 5.35(\mathrm{~s}, 2 \mathrm{H}), 2.53(\mathrm{t}$, 2H), 1.61-1.49 (m, 4H), 1.39-1.22 (m, 6H), $0.87(\mathrm{t}, 3 \mathrm{H}) .{ }^{13} \mathrm{C}$ NMR (101 MHz, DMSO) $\delta$ 168.03, 147.69, 147.24, 135.08, $123.45,121.74,114.11,52.18,31.34,29.20,28.12,25.39$, 24.46, 22.33, 14.36. ESI-MS: $(\mathrm{m} / \mathrm{z})$ calcd for $\mathrm{C}_{18} \mathrm{H}_{24} \mathrm{~N}_{6} \mathrm{O}$ : 340.42 , found $339.00(\mathrm{M}-\mathrm{H})^{+}$; anal. calcd for $\mathrm{C}_{18} \mathrm{H}_{24} \mathrm{~N}_{6} \mathrm{O}$ : (\%) C, 63.51; H, 7.11; N, 24.69; O, 4.70 found: C, 63.54; H, 7.17; N, $24.66 ; \mathrm{O}, 4.64$.

$\mathrm{N}$-(1H-Benzo[ $d]$ imidazol-2-yl)-2-(4-nonyl-1H-1,2,3-triazol1-yl)acetamide (6d). White; (55\%); m.p. $215-217{ }^{\circ} \mathrm{C}$; IR $\nu_{\max }$ $\left(\mathrm{KBr}, \mathrm{cm}^{-1}\right) 3339,3142,2962,1634,1591,1402 ;{ }^{1} \mathrm{H}$ NMR (400 MHz, DMSO) $\delta 12.13(\mathrm{~s}, 2 \mathrm{H}), 7.89(\mathrm{~s}, 1 \mathrm{H}), 7.45-7.40(\mathrm{dd}, J=$ $5.9,3.2 \mathrm{~Hz}, 2 \mathrm{H}), 7.12(\mathrm{dd}, J=5.9,3.2 \mathrm{~Hz}, 2 \mathrm{H}), 5.35(\mathrm{~s}, 2 \mathrm{H})$, $2.66(\mathrm{t}, 2 \mathrm{H}), 1.59(\mathrm{~m}, 2 \mathrm{H}), 1.36-1.23(\mathrm{~m}, 12 \mathrm{H}), 0.86(\mathrm{t}, 3 \mathrm{H}) .{ }^{13} \mathrm{C}$ NMR (101 MHz, DMSO) $\delta$ 168.01, 147.62, 147.13, 134.19, 122.46, 121.21, 113.08, 52.47, 31.34, 29.81, 29.74, 29.11, 28.12, 25.39, 24.46, 22.33, 14.36. ESI-MS: $(\mathrm{m} / \mathrm{z})$ calcd for $\mathrm{C}_{20} \mathrm{H}_{28} \mathrm{~N}_{6} \mathrm{O}$ : 368.48 , found $367.00(\mathrm{M}-\mathrm{H})^{+}$; anal. calcd for 
$\mathrm{C}_{20} \mathrm{H}_{28} \mathrm{~N}_{6} \mathrm{O}$ : (\%) C, 65.19; H, 7.66; N, 22.81; O, 4.34 found: C, $65.20 ; \mathrm{H}, 7.69 ; \mathrm{N}, 22.80 ; \mathrm{O}, 4.31$.

$\mathrm{N}$-(1H-Benzo[d]imidazol-2-yl)-2-(4-nonyl-1H-1,2,3-triazol1-yl)acetamide (6e). White; (92\%); m.p. 201-203 ${ }^{\circ} \mathrm{C}$; IR $\nu_{\max }$ $\left(\mathrm{KBr}, \mathrm{cm}^{-1}\right) 3391,3136,1641,1583,1399 ;{ }^{1} \mathrm{H}$ NMR $(400 \mathrm{MHz}$, DMSO) $\delta 12.62(\mathrm{~s}, 1 \mathrm{H}), 12.14(\mathrm{~s}, 2 \mathrm{H}), 8.13(\mathrm{~s}, 1 \mathrm{H}), 7.52(\mathrm{~m}, 1 \mathrm{H})$, $7.41(\mathrm{dd}, J=5.9,3.1 \mathrm{~Hz}, 3 \mathrm{H}), 7.24-6.99(\mathrm{~m}, 4 \mathrm{H}), 5.38(\mathrm{~s}, 2 \mathrm{H})$, $4.68(\mathrm{~s}, 2 \mathrm{H}) .{ }^{13} \mathrm{C}$ NMR (101 MHz, DMSO) $\delta$ 168.27, 150.05, 147.99, 144.11, 143.56, 125.67, 122.03, 121.65, 117.94, 114.01, 110.87, 53.04, 28.28. ESI-MS: $(\mathrm{m} / \mathrm{z})$ calcd for $\mathrm{C}_{19} \mathrm{H}_{16} \mathrm{~N}_{8} \mathrm{OS}$ : 404.45 , found $403.00(\mathrm{M}-\mathrm{H})^{+}$; anal. calcd for $\mathrm{C}_{19} \mathrm{H}_{16} \mathrm{~N}_{8} \mathrm{OS}$ : (\%) C, 56.42; H, 3.99; N, 27.71; O, 3.96; S, 7.93 found: C, 56.38; H, 4.12; N, 27.69; O, 3.97; S, 7.97.

$\mathrm{N}$-(1H-Benzo[d] imidazol-2-yl)-2-(4-((5-chloro-2-oxopyridin-1(2H)yl)methyl)-1H-1,2,3-triazol-1-yl)acetamide (6f). White; (86\%); m.p. $276-278{ }^{\circ} \mathrm{C}$; IR $\nu_{\max }\left(\mathrm{KBr}, \mathrm{cm}^{-1}\right) 3395,3135,1648,1583,1398 ;{ }^{1} \mathrm{H}$ NMR (400 MHz, DMSO) $\delta 12.15$ (s, 2H), 8.14 (s, 1H), 8.10 (dd, $J=$ 7.5, 3.0 Hz, 1H), 7.50 (dt, $J=8.9,4.4 \mathrm{~Hz}, 1 \mathrm{H}), 7.45-7.35(\mathrm{~m}, 2 \mathrm{H})$, 7.19-7.06 (m, 2H), $6.46(\mathrm{t}, J=8.9 \mathrm{~Hz}, 1 \mathrm{H}), 5.40(\mathrm{~s}, 2 \mathrm{H}), 5.16(\mathrm{~s}, 2 \mathrm{H})$. ${ }^{13} \mathrm{C}$ NMR (101 MHz, DMSO) $\delta$ 168.21, 160.26, 147.99, 142.43, 141.19, 137.22, 134.97, 126.12, 122.02, 121.37, 114.02, 110.86, 53.02, 44.02. ESI-MS: $(\mathrm{m} / \mathrm{z})$ calcd for $\mathrm{C}_{17} \mathrm{H}_{14} \mathrm{ClN}_{7} \mathrm{O}_{2}: 383.79$, found $382.00(\mathrm{M}-\mathrm{H})^{+}$; anal. calcd for $\mathrm{C}_{17} \mathrm{H}_{14} \mathrm{ClN}_{7} \mathrm{O}_{2}$ : (\%) C, 53.20; H, 3.68; Cl, 9.24; N, 25.55; O, 8.34 found: C, 53.25; H, 3.65; Cl, 9.28; N, 25.53; O, 8.30.

$\mathrm{N}$-(1H-Benzo[d]imidazol-2-yl)-2-(4-phenyl-1H-1,2,3-triazol-1yl)acetamide (6g). Brown; (45\%); m.p. 272-274 ${ }^{\circ} \mathrm{C}$; IR $\nu_{\max }$ $\left(\mathrm{KBr}, \mathrm{cm}^{-1}\right)$ 3385, 3101, 1646, 1595, 1401; ${ }^{1} \mathrm{H}$ NMR $(400 \mathrm{MHz}$, DMSO) $\delta 12.15(\mathrm{~s}, 2 \mathrm{H}), 8.62(\mathrm{~m}, 2 \mathrm{H}), 8.13(\mathrm{~s}, 1 \mathrm{H}), 7.79-7.40(\mathrm{~m}$, $4 \mathrm{H}), 7.31-6.83$ (m, 3H), 5.46 (s, 2H). ${ }^{13} \mathrm{C}$ NMR (101 MHz, DMSO) $\delta 168.51,147.23,142.71,141.38,136.48,135.82,125.21,124.98$, 122.02, 121.37, 114.02, 54.01. ESI-MS: $(\mathrm{m} / \mathrm{z})$ calcd for $\mathrm{C}_{17} \mathrm{H}_{14} \mathrm{~N}_{6} \mathrm{O}$ : 318.33, found $317.00(\mathrm{M}-\mathrm{H})^{+}$; anal. calcd for $\mathrm{C}_{17} \mathrm{H}_{14} \mathrm{~N}_{6} \mathrm{O}$ : (\%) C, 64.14; H, 4.43; N, 26.40; O, 5.03 found: C, 64.19; H, 4.42; N, 26.37; O, 5.01.

$\mathrm{N}$-(1H-Benzo[d]imidazol-2-yl)-2-(4-(4-fluorophenyl)-1H-1,2,3triazol-1-yl)acetamide (6h). White; (54\%); m.p. $283-285{ }^{\circ} \mathrm{C}$; IR $\nu_{\max }\left(\mathrm{KBr}, \mathrm{cm}^{-1}\right) 3381,3135,1632,1589,1406 .{ }^{1} \mathrm{H}$ NMR $(400$ MHz, DMSO) $\delta 12.09(\mathrm{~s}, 2 \mathrm{H}), 8.36(\mathrm{~s}, 1 \mathrm{H}), 7.87(\mathrm{~d}, J=8.5 \mathrm{~Hz}, 2 \mathrm{H})$, $7.64(\mathrm{~m}, 2 \mathrm{H}), 7.43$ (dd, $J=6.7,3.3 \mathrm{~Hz}, 2 \mathrm{H}), 7.12$ (dd, $J=6.7$, $3.3 \mathrm{~Hz}, 2 \mathrm{H}), 5.45$ (s, 2H). ${ }^{13} \mathrm{C}$ NMR (101 MHz, DMSO) $\delta 168.63$, 157.42, 148.37, 145.71, 134.89, 131.87, 130.16, 128.56, 124.14, 122.10, 121.26, 113.91, 54.45. ESI-MS: $(\mathrm{m} / \mathrm{z})$ calcd for $\mathrm{C}_{17} \mathrm{H}_{13} \mathrm{FN}_{6} \mathrm{O}$ : 336.32 , found $335.00(\mathrm{M}-1)^{+}$; anal. calcd for $\mathrm{C}_{17} \mathrm{H}_{13} \mathrm{FN}_{6} \mathrm{O}$ : (\%) C, 60.71; H, 3.90; F, 5.65; N, 24.99; O, 4.76 found: C, 60.74; H, 3.92; F, 5.66; N, 24.96; O, 4.73.

$\mathrm{N}$-(1H-Benzo[d]imidazol-2-yl)-2-(4-(4-chlorophenyl)-1H-1,2,3triazol-1-yl)acetamide (6i). White; (52\%); m.p. $269-271{ }^{\circ} \mathrm{C}$; IR $\nu_{\max }\left(\mathrm{KBr}, \mathrm{cm}^{-1}\right) 3348,3137,1644,1597,1403 ;{ }^{1} \mathrm{H}$ NMR $(400$ MHz, DMSO) $\delta 12.08(\mathrm{~s}, 2 \mathrm{H}), 8.37(\mathrm{~s}, 1 \mathrm{H}), 7.72(\mathrm{~d}, J=8.5 \mathrm{~Hz}, 2 \mathrm{H})$, $7.54(\mathrm{~d}, J=8.5 \mathrm{~Hz}, 2 \mathrm{H}), 7.41$ (dd, $J=6.7,3.3 \mathrm{~Hz}, 2 \mathrm{H}), 7.16-7.11$ (m, 2H), $5.47(\mathrm{~s}, 2 \mathrm{H}) .{ }^{13} \mathrm{C}$ NMR (101 MHz, DMSO) $\delta$ 168.65, 148.24, 146.52, 135.51, 132.45, 131.24, 130.86, 127.42, 123.87, 122.26, 121.27, 113.83, 53.41. ESI-MS: $(\mathrm{m} / \mathrm{z})$ calcd for $\mathrm{C}_{17} \mathrm{H}_{13} \mathrm{ClN}_{6} \mathrm{O}: 397.23$, found $395.00(\mathrm{M}-2)^{+}$; anal. calcd for $\mathrm{C}_{17} \mathrm{H}_{13} \mathrm{ClN}_{6} \mathrm{O}$ : (\%) C, 51.40; H, 3.30; Br, 20.12; N, 21.16; O, 4.03 found: C, 51.43; H, 3.32; Br, 20.10; N, 21.15; O, 4.04.
$\mathrm{N}$-(1H-Benzo[d]imidazol-2-yl)-2-(4-(4-bromophenyl)-1H1,2,3-triazol-1-yl)acetamide (6j). Brown; (82\%); m.p. 292$294{ }^{\circ} \mathrm{C}$; IR $\nu_{\max }\left(\mathrm{KBr}, \mathrm{cm}^{-1}\right) 3354,3112,1629,1594,1403 ;{ }^{1} \mathrm{H}$ NMR (400 MHz, DMSO) $\delta 12.20$ (s, 2H), 8.38 (s, 1H), 7.85 (d, J $=8.5 \mathrm{~Hz}, 2 \mathrm{H}), 7.67(\mathrm{~d}, J=8.5 \mathrm{~Hz}, 2 \mathrm{H}), 7.42(\mathrm{dd}, J=6.7$, $3.3 \mathrm{~Hz}, 2 \mathrm{H}), 7.18-7.08(\mathrm{~m}, 2 \mathrm{H}), 5.46(\mathrm{~s}, 2 \mathrm{H}) .{ }^{13} \mathrm{C}$ NMR (101 $\mathrm{MHz}, \mathrm{DMSO}) \delta 168.63,148.38,145.63,134.63,132.40$, 131.85, 130.52, 127.58, 123.86, 122.13, 121.28, 113.90, 53.41. ESI-MS: $(\mathrm{m} / \mathrm{z})$ calcd for $\mathrm{C}_{17} \mathrm{H}_{13} \mathrm{BrN}_{6} \mathrm{O}: 397.23$, found 395.00 $(\mathrm{M}-2)^{+}$; anal. calcd for $\mathrm{C}_{17} \mathrm{H}_{13} \mathrm{BrN}_{6} \mathrm{O}$ : (\%) C, 51.40; H, 3.30; $\mathrm{Br}, 20.12 ; \mathrm{N}, 21.16$; O, 4.03 found: C, 51.43; H, 3.32; $\mathrm{Br}$, $20.10 ; \mathrm{N}, 21.15 ; \mathrm{O}, 4.04$.

$\boldsymbol{N}$-(1H-Benzo[d]imidazol-2-yl)-2-(4-(p-tolyl)-1H-1,2,3-triazol-1yl)acetamide (6k). Off white; (70\%); m.p. 281-283 ${ }^{\circ} \mathrm{C}$; IR $\nu_{\max }$ $\left(\mathrm{KBr}, \mathrm{cm}^{-1}\right) 3376,3132,1645,1597,1405 ;{ }^{1} \mathrm{H}$ NMR $(400 \mathrm{MHz}$, DMSO) $\delta 12.19(\mathrm{~s}, 2 \mathrm{H}), 8.56(\mathrm{~s}, 1 \mathrm{H}), 7.77(\mathrm{~d}, J=8.0 \mathrm{~Hz}, 2 \mathrm{H}), 7.42$ (dd, $J=6.6,3.3 \mathrm{~Hz}, 2 \mathrm{H}), 7.28$ (d, $J=8.0 \mathrm{~Hz}, 2 \mathrm{H}), 7.17-7.09$ (m, $2 \mathrm{H}), 5.44(\mathrm{~s}, 2 \mathrm{H}), 2.34(\mathrm{~s}, 3 \mathrm{H}) .{ }^{13} \mathrm{C}$ NMR (101 MHz, DMSO) $\delta 168.51,148.23,146.73,137.60,129.73,129.50,128.50,125.54$, 123.06, 122.08, 113.95, 53.26, 21.30. ESI-MS: $(\mathrm{m} / \mathrm{z})$ calcd for $\mathrm{C}_{18} \mathrm{H}_{16} \mathrm{~N}_{6} \mathrm{O}$ : 332.36 , found $331.00(\mathrm{M}-\mathrm{H})^{+}$; anal. calcd for $\mathrm{C}_{18} \mathrm{H}_{16} \mathrm{~N}_{6} \mathrm{O}$ : (\%) C, 65.05; H, 4.85; N, 25.29; O, 4.81 found: $\mathrm{C}$, $65.11 ; \mathrm{H}, 4.82 ; \mathrm{N}, 25.30 ; \mathrm{O}, 4.83$.

$\mathrm{N}$-(1H-Benzo[d]imidazol-2-yl)-2-(4-(4-(tert-butyl)phenyl)-1H1,2,3-triazol-1-yl)acetamide (61). Off white; (67\%); m.p. 265$267{ }^{\circ} \mathrm{C}$; IR $\nu_{\max }\left(\mathrm{KBr}, \mathrm{cm}^{-1}\right) 3362,3123,1642,1599,1404 ;{ }^{1} \mathrm{H}$ NMR (400 MHz, DMSO) $\delta 12.07$ (s, 2H), 8.51 (s, 1H), 7.76 (d, $J=$ $8.0 \mathrm{~Hz}, 2 \mathrm{H}), 7.41(\mathrm{dd}, J=6.6,3.3 \mathrm{~Hz}, 2 \mathrm{H}), 7.18(\mathrm{~d}, J=8.0 \mathrm{~Hz}$, 2H), 7.15-7.05 (m, 2H), 5.42 (s, 2H), 1.33 (s, 9H). ${ }^{13} \mathrm{C}$ NMR (101 MHz, DMSO) $\delta 168.43,148.24,146.71,137.41,129.01,129.67$, 128.61, 125.55, 123.09, 121.22, 114.05, 53.22, 35.79, 32.41. ESIMS: $(m / z)$ calcd for $\mathrm{C}_{21} \mathrm{H}_{22} \mathrm{~N}_{6} \mathrm{O}: 374.44$, found $373.00(\mathrm{M}-\mathrm{H})^{+}$; anal. calcd for $\mathrm{C}_{21} \mathrm{H}_{22} \mathrm{~N}_{6} \mathrm{O}$ : (\%) C, 67.36; H, 5.92; N, 22.44; O, 4.27 found: C, 67.39; H, 5.90; N, 22.41; O, 4.29.

$\mathrm{N}$-(1H-Benzo[d]imidazol-2-yl)-2-(4-(4-hydroxyphenyl)-1H1,2,3-triazol-1-yl)acetamide (6m). Brown gummy solid; (46\%); IR $\nu_{\max }\left(\mathrm{KBr}, \mathrm{cm}^{-1}\right) 3365,3142,1634,1596,1403 ;{ }^{1} \mathrm{H}$ NMR (400 MHz, DMSO) $\delta 12.13$ (s, 2H), 8.38 (s, 1H), 7.72 (d, J $=8.5 \mathrm{~Hz}, 2 \mathrm{H}), 7.41(\mathrm{dd}, J=6.7,3.3 \mathrm{~Hz}, 2 \mathrm{H}), 7.16-7.11(\mathrm{~m}, 2 \mathrm{H})$, $6.91(\mathrm{~d}, J=8.5 \mathrm{~Hz}, 2 \mathrm{H}), 6.7$ (bs, $1 \mathrm{H}), 5.57$ (s, 2H). ${ }^{13} \mathrm{C} \mathrm{NMR}$ (101 MHz, DMSO) $\delta 168.43,156.75,148.23,146.61,135.42$, 131.09, 130.81, 126.44, 123.88, 122.12, 121.23, 113.49, 54.98. ESI-MS: $(m / z)$ calcd for $\mathrm{C}_{17} \mathrm{H}_{14} \mathrm{~N}_{6} \mathrm{O}_{2}: 334.33$, found $333.00(\mathrm{M}-$ $2)^{+}$; anal. calcd for $\mathrm{C}_{17} \mathrm{H}_{14} \mathrm{~N}_{6} \mathrm{O}_{2}$ : (\%) C, 61.07; H, 4.22; N, 25.14; O, 9.57 found: C, 61.10; H, 4.21; N, 25.15; O, 9.54.

$\boldsymbol{N}$-(1H-Benzo[ $d]$ imidazol-2-yl)-2-(4-(4-methoxyphenyl)-1H1,2,3-triazol-1-yl)acetamide (6n). Pale yellow; (48\%); m.p. 242-243 ${ }^{\circ} \mathrm{C}$; IR $\nu_{\max }\left(\mathrm{KBr}, \mathrm{cm}^{-1}\right) 3343,3107,1646,1598,1405$; ${ }^{1} \mathrm{H}$ NMR (400 MHz, DMSO) $\delta 12.16$ (s, 2H), 8.36 (s, 1H), 7.75 $(\mathrm{d}, J=8.4 \mathrm{~Hz}, 2 \mathrm{H}), 7.62(\mathrm{~d}, J=8.4 \mathrm{~Hz}, 2 \mathrm{H}), 7.40(\mathrm{dd}, J=6.7$, $3.3 \mathrm{~Hz}, 2 \mathrm{H}), 7.16-7.07(\mathrm{~m}, 2 \mathrm{H}), 5.46(\mathrm{~s}, 2 \mathrm{H}), 3.78(\mathrm{~s}, 3 \mathrm{H}) .{ }^{13} \mathrm{C}$ NMR (101 MHz, DMSO) $\delta$ 168.73, 159.41, 147.63, 135.13, 132.42, 131.87, 130.47, 127.64, 123.26, 122.14, 121.38, 113.91, 53.42, 54.47. ESI-MS: $(\mathrm{m} / z)$ calcd for $\mathrm{C}_{18} \mathrm{H}_{16} \mathrm{~N}_{6} \mathrm{O}_{2}: 348.36$, found $347.00(\mathrm{M}-2)^{+}$; anal. calcd for $\mathrm{C}_{18} \mathrm{H}_{16} \mathrm{~N}_{6} \mathrm{O}_{2}$ : (\%) C, 
62.06; H, 4.63; N, 24.12; O, 9.19 found: C, 62.11; H, 4.61; N, $24.11 ; \mathrm{O}, 9.17$.

$\mathrm{N}$-(1H-Benzo[d] imidazol-2-yl)-2-(4-(4-(trifluoromethyl)phenyl)1H-1,2,3-triazol-1-yl)acetamide (6o). White; (72\%); m.p. 286$288^{\circ} \mathrm{C}$; IR $\nu_{\max }\left(\mathrm{KBr}, \mathrm{cm}^{-1}\right) 3383,3107,1654,1599,1404 ;{ }^{1} \mathrm{H}$ NMR (400 MHz, DMSO) $\delta 12.06(\mathrm{~s}, 2 \mathrm{H}), 8.66(\mathrm{~s}, 1 \mathrm{H}), 7.96(\mathrm{~d}, J=8.1 \mathrm{~Hz}$, $2 \mathrm{H}), 7.69(\mathrm{~d}, J=8.3 \mathrm{~Hz}, 2 \mathrm{H}), 7.31-7.24(\mathrm{~m}, 2 \mathrm{H}), 7.02-6.95(\mathrm{~m}, 2 \mathrm{H})$, 5.33 (s, 2H). ${ }^{13} \mathrm{C}$ NMR (101 MHz, DMSO) $\delta 168.69,148.44,145.30$, 135.23, 134.59, 128.62, 128.31, 126.44, 124.78, 123.38, 122.15, 113.87, 53.50. ESI-MS: $(\mathrm{m} / \mathrm{z})$ calcd for $\mathrm{C}_{18} \mathrm{H}_{13} \mathrm{~F}_{3} \mathrm{~N}_{6} \mathrm{O}: 386.33$, found $385.00(\mathrm{M}-\mathrm{H})^{+}$; anal. calcd for $\mathrm{C}_{18} \mathrm{H}_{13} \mathrm{~F}_{3} \mathrm{~N}_{6} \mathrm{O}$ : (\%) C, 55.96; H, 3.39; F, 14.75; N, 21.75; O, 4.14 found: C, 60.01; H, 3.40; F, 14.72; N, $21.71 ; \mathrm{O}, 4.15$.

$N$-(1H-Benzo[ $d]$ imidazol-2-yl)-2-(4-(4-nitrophenyl)-1H-1,2,3triazol-1-yl)acetamide (6p). Pale yellow; (68\%); m.p. 283$285{ }^{\circ} \mathrm{C}$; IR $\nu_{\max }\left(\mathrm{KBr}, \mathrm{cm}^{-1}\right) 3358,3104,1638,1595,1403 ;{ }^{1} \mathrm{H}$ NMR (400 MHz, DMSO) $\delta 12.28(\mathrm{~s}, 2 \mathrm{H}), 8.96(\mathrm{~s}, 1 \mathrm{H}), 8.40$ (d, $J=$ $8.9 \mathrm{~Hz}, 2 \mathrm{H}), 8.23(\mathrm{~d}, J=8.8 \mathrm{~Hz}, 2 \mathrm{H}), 7.48$ (dd, $J=5.9,3.2 \mathrm{~Hz}$, 2H), 7.25-7.12 (m, 2H), $5.56(\mathrm{~s}, 2 \mathrm{H}) .{ }^{13} \mathrm{C}$ NMR (101 MHz, DMSO) $\delta$ 168.79, 148.54, 147.07, 147.78, 137.66, 126.37, 125.63, 124.93, 124.36, 122.19, 113.81, 53.62. ESI-MS: $(\mathrm{m} / \mathrm{z})$ calcd for $\mathrm{C}_{17} \mathrm{H}_{13} \mathrm{~N}_{7} \mathrm{O}_{3}: 363.33$, found $362.00(\mathrm{M}-\mathrm{H})^{+}$; anal. calcd for $\mathrm{C}_{17} \mathrm{H}_{13} \mathrm{~N}_{7} \mathrm{O}_{3}$ : (\%) C, 56.20; H, 3.61; N, 26.99; O, 13.21 found: C, C, 56.24; H, 3.59; N, 26.96; O, 13.22.

$\mathrm{N}$-(1H-Benzo[d]imidazol-2-yl)-2-(4-(3-nitrophenyl)-1H-1,2,3triazol-1-yl)acetamide (6q). Yellow; (64\%); m.p. $240-242{ }^{\circ} \mathrm{C}$; IR $\nu_{\max }\left(\mathrm{KBr}, \mathrm{cm}^{-1}\right) 3357,3120,1642,1596,1403 ;{ }^{1} \mathrm{H}$ NMR $(400$ MHz, DMSO) 12.26 (s, 2H), 8.91 (s, 1H), 8.32 (m, 2H), 8.21 (d, $=6.8 \mathrm{~Hz}, 1 \mathrm{H}), 7.79(\mathrm{t}, J=7.8 \mathrm{~Hz}, 1 \mathrm{H}), 7.42(\mathrm{dd}, J=5.5,3.1 \mathrm{~Hz}$, $2 \mathrm{H}), 7.13$ (dd, $J=5.4,3.2 \mathrm{~Hz}, 2 \mathrm{H}), 5.49$ (s, 2H). ${ }^{13} \mathrm{C}$ NMR (101 MHz, DMSO) $\delta 168.25,148.44,148.18,147.13,137.52,1345.41$, 133.46, 126.77, 125.47, 124.82, 124.53, 122.67, 113.22, 53.41. ESI-MS: $(\mathrm{m} / \mathrm{z})$ calcd for $\mathrm{C}_{17} \mathrm{H}_{13} \mathrm{~N}_{7} \mathrm{O}_{3}: 363.33$, found $362.00(\mathrm{M}-$ $\mathrm{H})^{+}$; anal. calcd for $\mathrm{C}_{17} \mathrm{H}_{13} \mathrm{~N}_{7} \mathrm{O}_{3}$ : (\%) C, 56.20; H, 3.61; N, 26.99; O, 13.21 found: C, 56.22; H, 3.57; N, 26.97; O, 13.21.

$\mathrm{N}$-(5,6-Dimethyl-1H-benzo[d]imidazol-2-yl)-2-(4-propyl-1H-1,2,3triazol-1-yl)acetamide (7a). White; (73\%); m.p. $241-243{ }^{\circ} \mathrm{C}$; IR $\nu_{\max }$ $\left(\mathrm{KBr}, \mathrm{cm}^{-1}\right) 3367,3134,1692,1598,1401 ;{ }^{1} \mathrm{H}$ NMR $(400 \mathrm{MHz}$, DMSO) $\delta 11.99(\mathrm{~s}, 2 \mathrm{H}), 7.88(\mathrm{~s}, 1 \mathrm{H}), 7.18(\mathrm{~s}, 2 \mathrm{H}), 5.30(\mathrm{~s}, 2 \mathrm{H}), 2.62(\mathrm{t}$, $2 \mathrm{H}), 2.26(\mathrm{~s}, 6 \mathrm{H}), 1.69-1.56(\mathrm{~m}, 2 \mathrm{H}), 0.93(\mathrm{t}, 3 \mathrm{H}) .{ }^{13} \mathrm{C}$ NMR $(101$ MHz, DMSO) $\delta 168.95,148.07,146.92,132.79,130.27,123.90$, 114.12, 53.13, 27.51, 22.79, 20.30, 14.05. ESI-MS: $(\mathrm{m} / \mathrm{z})$ calcd for $\mathrm{C}_{16} \mathrm{H}_{20} \mathrm{~N}_{6} \mathrm{O}$ : 312.37, found $300.00(\mathrm{M}-\mathrm{H})^{+}$; anal. calcd for $\mathrm{C}_{16} \mathrm{H}_{20} \mathrm{~N}_{6} \mathrm{O}$ : (\%) C, 61.52; H, 6.45; N, 26.90; O, 5.12 found: C, 61.56; H, 6.43; N, 26.86; O, 5.14.

$\mathrm{N}$-(5,6-Dimethyl-1H-benzo[d]imidazol-2-yl)-2-(4-pentyl-1H-1,2,3triazol-1-yl)acetamide (7b). Off white; (66\%); m.p. 200-202 ${ }^{\circ} \mathrm{C}$; IR $\nu_{\max }\left(\mathrm{KBr}, \mathrm{cm}^{-1}\right) 3374,3132,1682,1584,1407 ;{ }^{1} \mathrm{H}$ NMR $(400 \mathrm{MHz}$, DMSO) $\delta 12.09(\mathrm{~s}, 2 \mathrm{H}), 7.87(\mathrm{~s}, 1 \mathrm{H}), 7.18(\mathrm{~s}, 2 \mathrm{H}), 5.29(\mathrm{~s}, 2 \mathrm{H}), 2.64(\mathrm{t}$, $2 \mathrm{H}), 2.26(\mathrm{~s}, 6 \mathrm{H}), 1.64-1.56(\mathrm{~m}, 2 \mathrm{H}), 1.32(\mathrm{~m}, 4 \mathrm{H}), 0.87(\mathrm{t}, 3 \mathrm{H}) .{ }^{13} \mathrm{C}$ NMR (101 MHz, DMSO) $\delta$ 168.92, 147.98, 147.16, 132.91, 130.26, $123.85,114.12$, 53.14, 31.23, 29.19, 25.40, 22.33, 20.29, 14.35. ESIMS: $(\mathrm{m} / \mathrm{z})$ calcd for $\mathrm{C}_{18} \mathrm{H}_{24} \mathrm{~N}_{6} \mathrm{O}: 340.42$, found $339.00(\mathrm{M}-\mathrm{H})^{+}$; anal. calcd for $\mathrm{C}_{18} \mathrm{H}_{24} \mathrm{~N}_{6} \mathrm{O}$ : (\%) C, 63.51; H, 7.11; N, 24.69; O, 4.70 found: C, 63.54; H, 7.13; N, 24.67; O, 4.67.

$\boldsymbol{N}$-(5,6-Dimethyl-1H-benzo[d]imidazol-2-yl)-2-(4-heptyl-1H-1,2,3triazol-1-yl)acetamide (7c). Grey colour; (57\%); m.p. 209-211 ${ }^{\circ} \mathrm{C}$; IR $\nu_{\max }\left(\mathrm{KBr}, \mathrm{cm}^{-1}\right) 3369,3124,1691,1594,1403 ;{ }^{1} \mathrm{H}$ NMR $(400 \mathrm{MHz}$, DMSO) $\delta 12.12(\mathrm{~s}, 2 \mathrm{H}), 7.87(\mathrm{~s}, 1 \mathrm{H}), 7.18(\mathrm{~s}, 2 \mathrm{H}), 5.29(\mathrm{~s}, 2 \mathrm{H}), 2.36(\mathrm{t}$, $2 \mathrm{H}), 2.26(\mathrm{~s}, 2 \mathrm{H}), 1.62-1.50(\mathrm{~m}, 6 \mathrm{H}), 1.38-1.23(\mathrm{~m}, 8 \mathrm{H}), 0.84(\mathrm{t}, 3 \mathrm{H})$. ${ }^{13} \mathrm{C}$ NMR (101 MHz, DMSO) $\delta$ 168.90, 147.96, 147.11, 132.91, 130.22 , 123.81, 114.15, 53.16, 31.24, 29.13, 28.95, 25.41, 22.23, 20.29, 19.18, 14.36. ESI-MS: $(\mathrm{m} / \mathrm{z})$ calcd for $\mathrm{C}_{20} \mathrm{H}_{28} \mathrm{~N}_{6} \mathrm{O}: 368.48$, found $367.00(\mathrm{M}-\mathrm{H})^{+}$; anal. calcd for $\mathrm{C}_{20} \mathrm{H}_{28} \mathrm{~N}_{6} \mathrm{O}$ : (\%) C, 65.19; $\mathrm{H}$, 7.66; N, 22.81; O, 4.34 found: C, 65.23; H, 7.64; N, 22.77; O, 4.36.

$\mathrm{N}$-(5,6-Dimethyl-1H-benzo[d]imidazol-2-yl)-2-(4-nonyl-1H1,2,3-triazol-1-yl)acetamide (7d). Off white; (55\%); m.p. 194$196{ }^{\circ} \mathrm{C}$; IR $\nu_{\max }\left(\mathrm{KBr}, \mathrm{cm}^{-1}\right) 3358,3112,1684,1598,1406 ;{ }^{1} \mathrm{H}$ NMR (400 MHz, DMSO) $\delta 12.03$ (s, 2H), 7.87 (s, 1H), 7.18 (s, $2 \mathrm{H}), 5.29(\mathrm{~s}, 2 \mathrm{H}), 2.63(\mathrm{t}, 2 \mathrm{H}), 2.25(\mathrm{~s}, 6 \mathrm{H}), 1.60(\mathrm{~m}, 2 \mathrm{H}), 1.31-$ $1.28(\mathrm{~m}, 4 \mathrm{H}), 1.27-1.23(\mathrm{~s}, 8 \mathrm{H}), 0.85(\mathrm{t}, 3 \mathrm{H}) .{ }^{13} \mathrm{C}$ NMR (101 MHz, DMSO) $\delta 168.72,148.47,147.50,133.55,130.26,123.66$, 114.06, 53.13, 31.77, 29.54, 29.44, 29.29, 29.19, 29.05, 25.45, 22.57, 20.30, 14.42. ESI-MS: $(\mathrm{m} / z)$ calcd for $\mathrm{C}_{22} \mathrm{H}_{32} \mathrm{~N}_{6} \mathrm{O}$ : 396.53 , found $395.00(\mathrm{M}-\mathrm{H})^{+}$; anal. calcd for $\mathrm{C}_{22} \mathrm{H}_{32} \mathrm{~N}_{6} \mathrm{O}$ : (\%) C, 66.64; H, 8.13; N, 21.19; O, 4.03 found: C, 66.66; H, 8.11; N, 21.17; O, 4.05 .

2-(4-(((1H-Benzo[d]imidazol-2-yl)thio)methyl)-1H-1,2,3-triazol-1-yl)- $N$-(5,6-dimethyl-1H-benzo[d]imidazol-2-yl)

acetamide (7e). Off white; (84\%); m.p. $194-196{ }^{\circ} \mathrm{C}$; IR $\nu_{\max }$ $\left(\mathrm{KBr}, \mathrm{cm}^{-1}\right) 3371,3132,1691,1594,1405 ;{ }^{1} \mathrm{H}$ NMR $(400 \mathrm{MHz}$, DMSO) $\delta 12.62(\mathrm{~s}, 2 \mathrm{H}), 11.19(\mathrm{~s}, 1 \mathrm{H}), 8.16(\mathrm{~s}, 1 \mathrm{H}), 7.60(\mathrm{~m}, 2 \mathrm{H})$, 7.43 (dd, $J=5.9,3.1 \mathrm{~Hz}, 2 \mathrm{H}), 7.19$ (s, 2H), 5.37 (s, 2H), 4.43 (s, 2H), 2.31 (s, 6H). ${ }^{13} \mathrm{C}$ NMR (101 MHz, DMSO) $\delta$ 168.26, 150.24, 148.01, 144.08, 143.53, 125.67, 122.04, 121.68, 117.91, 114.00, 110.67, 53.06, 28.48, 20.18. ESI-MS: $(\mathrm{m} / \mathrm{z})$ calcd for $\mathrm{C}_{21} \mathrm{H}_{20} \mathrm{~N}_{8} \mathrm{OS}$ : 432.50 , found $431.00(\mathrm{M}-\mathrm{H})^{+}$; anal. calcd for $\mathrm{C}_{21} \mathrm{H}_{20} \mathrm{~N}_{8} \mathrm{OS}$ : (\%) C, 58.32; H, 4.66; N, 25.91; O, 3.70; S, 7.41 found: C, 58.35; H, 4.68; N, 25.89; O, 3.69; S, 7.40.

2-(4-((5-Chloro-2-oxopyridin-1(2H)-yl)methyl)-1H-1,2,3-triazol-1-yl)- $\mathrm{N}$-(5,6-dimethyl-1H-benzo[d]imidazol-2-yl)

acetamide (7f). White; (83\%); m.p. 281-283 ${ }^{\circ} \mathrm{C}$; IR $\nu_{\max }$ $\left(\mathrm{KBr}, \mathrm{cm}^{-1}\right)$ 3369, 3131, 1694, 1593, 1409; ${ }^{1} \mathrm{H}$ NMR $(400 \mathrm{MHz}$, DMSO) $\delta 12.01(\mathrm{~s}, 2 \mathrm{H}), 8.11(\mathrm{~m}, 2 \mathrm{H}), 7.51(\mathrm{dd}, J=9.7,2.9 \mathrm{~Hz}$, $1 \mathrm{H}), 7.17(\mathrm{~s}, 2 \mathrm{H}), 6.47$ (d, $J=9.7 \mathrm{~Hz}, 1 \mathrm{H}), 5.33(\mathrm{~s}, 2 \mathrm{H}), 5.17$ (s, $2 \mathrm{H}), 2.26$ (s, 6H). ${ }^{13} \mathrm{C}$ NMR (101 MHz, DMSO) $\delta 160.16,142.36$, 141.51, 141.51, 137.22, 136.84, 126.05, 121.37, 121.23, 113.99, 110.86, 53.41, 44.00, 20.29. ESI-MS: $(\mathrm{m} / \mathrm{z})$ calcd for $\mathrm{C}_{19} \mathrm{H}_{18} \mathrm{ClN}_{7} \mathrm{O}_{2}: 411.84$, found $410.00(\mathrm{M}-\mathrm{H})^{+}$; anal. calcd for $\mathrm{C}_{19} \mathrm{H}_{18} \mathrm{ClN}_{7} \mathrm{O}_{2}$ : (\%) C, 55.41; H, 4.41; Cl, 8.61; N, 23.81; O, 7.77 found: C, 55.44; H, 4.43; Cl, 8.60; N, 23.80; O, 7.73.

$\mathrm{N}$-(5,6-Dimethyl-1H-benzo[d]imidazol-2-yl)-2-(4-phenyl-1H1,2,3-triazol-1-yl)acetamide (7g). Dark brown gummy solid; (47\%); IR $\nu_{\max }\left(\mathrm{KBr}, \mathrm{cm}^{-1}\right) 3358,3137,1671,1584,1404 ;{ }^{1} \mathrm{H}$ NMR (400 MHz, DMSO) $\delta 12.03(\mathrm{~s}, 2 \mathrm{H}), 8.37$ (s, 1H), 7.73 (d, $J=$ $7.8 \mathrm{~Hz}, 2 \mathrm{H}), 7.41-7.32(\mathrm{~m}, 3 \mathrm{H}), 7.17(\mathrm{~s}, 2 \mathrm{H}), 5.34(\mathrm{~s}, 2 \mathrm{H}), 2.23(\mathrm{~s}$, $6 \mathrm{H}) .{ }^{13} \mathrm{C}$ NMR (101 MHz, DMSO) $\delta$ 168.43, 147.18, 146.45, 136.89, 129.84, 1298.40, 127.51, 125.59, 122.34, 113.91, 53.25, 21.30. ESI-MS: $(\mathrm{m} / \mathrm{z})$ calcd for $\mathrm{C}_{19} \mathrm{H}_{18} \mathrm{~N}_{6} \mathrm{O}: 346.39$, found 345.00 $(\mathrm{M}-\mathrm{H})^{+}$; anal. calcd for $\mathrm{C}_{19} \mathrm{H}_{18} \mathrm{~N}_{6} \mathrm{O}$ : (\%) C, 65.88; $\mathrm{H}, 5.24 ; \mathrm{N}$, 24.26; O, 4.62 found: C, 65.90; H, 5.28; N, 24.24; O, 4.58.

2-(4-(4-Bromophenyl)-1H-1,2,3-triazol-1-yl)- $\mathrm{N}$-(5,6-dimethyl1H-benzo[d] imidazol-2-yl)acetamide (7h). White; (76\%); m.p. 273-275 ${ }^{\circ} \mathrm{C}$; IR $\nu_{\max }\left(\mathrm{KBr}, \mathrm{cm}^{-1}\right) 3349,3137,1691,1588,1407 ;{ }^{1} \mathrm{H}$ 
NMR (400 MHz, DMSO) $\delta 12.04(\mathrm{~s}, 2 \mathrm{H}), 8.55$ (s, 1H), 7.41 (dd, $J=$ 6.7, 3.3 Hz, 2H), 7.12-7.09 (m, 2H), 7.18 (s, 2H), 5.37 (s, 2H), 2.26 (s, 6H). ${ }^{13} \mathrm{C}$ NMR (101 MHz, DMSO) $\delta 168.51,148.17,146.25$, 137.11, 129.69, 129.41, 128.22, 125.69, 123.63, 122.34, 114.12, 53.24, 21.29. ESI-MS: $(\mathrm{m} / \mathrm{z})$ calcd for $\mathrm{C}_{19} \mathrm{H}_{17} \mathrm{BrN}_{6} \mathrm{O}: 425.28$, found $424.00(\mathrm{M}-\mathrm{H})^{+}$; anal. calcd for $\mathrm{C}_{19} \mathrm{H}_{17} \mathrm{BrN}_{6} \mathrm{O}$ : (\%) C, 53.66; $\mathrm{H}, 4.03$; Br, 18.79; N, 19.76; O, 3.76, found: C, 53.71; H, 4.00; Br, 18.77; N, 19.78; O, 3.74.

$N$-(5,6-Dimethyl-1H-benzo[d]imidazol-2-yl)-2-(4-( $p$-tolyl)1H-1,2,3-triazol-1-yl)acetamide (7i). Pale yellow; (55\%); m.p. 258-260 ${ }^{\circ} \mathrm{C}$; IR $\nu_{\max }\left(\mathrm{KBr}, \mathrm{cm}^{-1}\right) 3386,3127,1639,1592$, $1404 ;{ }^{1} \mathrm{H}$ NMR (400 MHz, DMSO) $\delta 12.06(\mathrm{~s}, 2 \mathrm{H}), 8.54(\mathrm{~s}, 1 \mathrm{H})$, $7.76(\mathrm{~d}, J=7.8 \mathrm{~Hz}, 2 \mathrm{H}), 7.27(\mathrm{~d}, J=7.8 \mathrm{~Hz}, 2 \mathrm{H}), 7.18(\mathrm{~s}, 2 \mathrm{H})$, $5.37(\mathrm{~s}, 2 \mathrm{H}), 2.34(\mathrm{~s}, 3 \mathrm{H}), 2.26(\mathrm{~s}, 6 \mathrm{H}) .{ }^{13} \mathrm{C} \mathrm{NMR}(101 \mathrm{MHz}$, DMSO) $\delta 168.53,148.17,146.45,137.89,129.86,129.40$, 128.52, 125.59, 123.67, 122.33, 113.94, 53.25, 21.30, 20.24. ESI-MS: $(\mathrm{m} / \mathrm{z})$ calcd for $\mathrm{C}_{20} \mathrm{H}_{20} \mathrm{~N}_{6} \mathrm{O}: 360.41$, found $359.00(\mathrm{M}-$ $\mathrm{H})^{+}$; anal. calcd for $\mathrm{C}_{20} \mathrm{H}_{20} \mathrm{~N}_{6} \mathrm{O}$ : (\%) C, 66.65; H, 5.59; N, 23.32 ; O, 4.44 found: C, 66.68; H, 5.56; N, 23.34; O, 4.42.

$\mathrm{N}$-(5,6-Dimethyl-1H-benzo[d]imidazol-2-yl)-2-(4-(4-hydroxyphenyl)-1H-1,2,3-triazol-1-yl)acetamide (7j). Brown; (65\%); m.p. $326-328{ }^{\circ} \mathrm{C}$; IR $\nu_{\max }\left(\mathrm{KBr}, \mathrm{cm}^{-1}\right) 3378,3136,1684,1594$, 1409; ${ }^{1} \mathrm{H}$ NMR (400 MHz, DMSO) $\delta 11.85$ (s, 2H), 8.49 (s, 1H), $7.83(\mathrm{~d}, J=8.1 \mathrm{~Hz}, 2 \mathrm{H}), 7.66(\mathrm{~d}, J=8.2 \mathrm{~Hz}, 2 \mathrm{H}), 7.19(\mathrm{~s}, 2 \mathrm{H})$, 6.83 (bs, 1H) 5.22 (s, 2H), $2.23(\mathrm{~s}, 6 \mathrm{H}) .{ }^{13} \mathrm{C}$ NMR (101 MHz, DMSO) $\delta 168.41,148.34,136.21,131.69,128.53,128.24$, 126.19, 126.37, 123.82, 122.39, 113.77, 53.58, 20.35. ESI-MS: $(\mathrm{m} / \mathrm{z})$ calcd for $\mathrm{C}_{19} \mathrm{H}_{18} \mathrm{~N}_{6} \mathrm{O}_{2}: 362.39$, found $361.00(\mathrm{M}-\mathrm{H})^{+}$; anal. calcd for $\mathrm{C}_{19} \mathrm{H}_{18} \mathrm{~N}_{6} \mathrm{O}_{2}$ : (\%) C, 62.97; H, 5.01; N, 23.19; O, 8.83 found: C, 62.99; H, 5.04; N, 23.16; O, 8.81.

$N$-(5,6-Dimethyl-1H-benzo[ $d]$ imidazol-2-yl)-2-(4-(4-methoxyphenyl)-1H-1,2,3-triazol-1-yl)acetamide (7k). Pale yellow; (58\%); m.p. $283-285{ }^{\circ} \mathrm{C}$; IR $\nu_{\max }\left(\mathrm{KBr}, \mathrm{cm}^{-1}\right) 3338,3127,1672$, 1598, 1402; ${ }^{1} \mathrm{H}$ NMR (400 MHz, DMSO) $\delta 12.03(\mathrm{~s}, 2 \mathrm{H}), 8.49$ (s, $1 \mathrm{H}), 7.96(\mathrm{~d}, J=8.1 \mathrm{~Hz}, 2 \mathrm{H}), 7.81(\mathrm{~d}, J=8.2 \mathrm{~Hz}, 2 \mathrm{H}), 7.00(\mathrm{~s}$, 2H), $5.36(\mathrm{~s}, 2 \mathrm{H}), 3.78(\mathrm{~s}, 3 \mathrm{H}) 2.23(\mathrm{~s}, 6 \mathrm{H}) .{ }^{13} \mathrm{C}$ NMR $(101 \mathrm{MHz}$, DMSO) $\delta 168.33,148.42,136.93,131.17,128.73,126.81$, 126.73, 123.64, 121.82, 113.37, 53.71, 51.47, 20.32. ESI-MS: $(\mathrm{m} /$ z) calcd for $\mathrm{C}_{20} \mathrm{H}_{20} \mathrm{~N}_{6} \mathrm{O}_{2}$ : 376.41, found $375.00(\mathrm{M}-\mathrm{H})^{+}$; anal. calcd for $\mathrm{C}_{20} \mathrm{H}_{20} \mathrm{~N}_{6} \mathrm{O}_{2}$ : (\%) C, 63.82; H, 5.36; N, 22.33; O, 8.50 found: C, 63.87; H, 5.34; N, 22.32; O, 8.49.

$N$-(5,6-Dimethyl-1H-benzo[ $d]$ imidazol-2-yl)-2-(4-(4-(trifluoromethyl)phenyl)-1H-1,2,3-triazol-1-yl)acetamide (7l). Pale yellow; (66\%); m.p. $273-275{ }^{\circ} \mathrm{C}$; IR $\nu_{\max }\left(\mathrm{KBr}, \mathrm{cm}^{-1}\right)$ 3385, 3142, 1694, 1527, 1402; ${ }^{1} \mathrm{H}$ NMR (400 MHz, DMSO) $\delta 11.93(\mathrm{~s}, 2 \mathrm{H}), 8.64(\mathrm{~s}, 1 \mathrm{H}), 7.96(\mathrm{~d}, J=8.1 \mathrm{~Hz}, 2 \mathrm{H}), 7.68(\mathrm{~d}$, $J=8.2 \mathrm{~Hz}, 2 \mathrm{H}), 7.03(\mathrm{~s}, 2 \mathrm{H}), 5.22(\mathrm{~s}, 2 \mathrm{H}), 2.10(\mathrm{~s}, 6 \mathrm{H}) .{ }^{13} \mathrm{C}$ NMR (101 MHz, DMSO) $\delta$ 169.69, 145.24, 135.29, 130.54, $128.56,128.24,126.45,126.09,124.74,123.39,113.78$, 53.91, 20.28. ESI-MS: $(\mathrm{m} / \mathrm{z})$ calcd for $\mathrm{C}_{20} \mathrm{H}_{17} \mathrm{~F}_{3} \mathrm{~N}_{6} \mathrm{O}: 314.38$, found $313.00(\mathrm{M}-\mathrm{H})^{+}$; anal. calcd for $\mathrm{C}_{20} \mathrm{H}_{17} \mathrm{~F}_{3} \mathrm{~N}_{6} \mathrm{O}$ : (\%) C, 57.97; H, 4.14; F, 13.75; N, 20.28; O, 3.86 ffound: C, 57.99; $\mathrm{H}, 4.18 ; \mathrm{F}, 13.74 ; \mathrm{N}, 20.26$; O, 3.83 .

$\boldsymbol{N}$-(5,6-Dimethyl-1H-benzo[d]imidazol-2-yl)-2-(4-(4-nitrophenyl)-1H-1,2,3-triazol-1-yl)acetamide (7m). Pale yellow; (71\%); m.p. $288-289{ }^{\circ} \mathrm{C}$; IR $\nu_{\max }\left(\mathrm{KBr}, \mathrm{cm}^{-1}\right) 3346,3148$, 1686, 1585, 1406; ${ }^{1} \mathrm{H}$ NMR (400 MHz, DMSO) $\delta 12.09$ (s, 2H), $8.89(\mathrm{~s}, 1 \mathrm{H}), 8.31(\mathrm{~d}, J=7.9 \mathrm{~Hz}, 2 \mathrm{H}), 8.16(\mathrm{~d}, J=7.9 \mathrm{~Hz}, 2 \mathrm{H})$, $7.18(\mathrm{~s}, 2 \mathrm{H}), 5.42(\mathrm{~s}, 2 \mathrm{H}), 2.26(\mathrm{~s}, 6 \mathrm{H}) .{ }^{13} \mathrm{C}$ NMR $(101 \mathrm{MHz}$, DMSO) $\delta$ 169.68, 145.28, 135.45, 131.07, 128.67, 128.38, 127.02, 126.01, 124.75, 123.43, 113.76, 53.92, 20.29. ESI-MS: $(\mathrm{m} / \mathrm{z})$ calcd for $\mathrm{C}_{19} \mathrm{H}_{17} \mathrm{~N}_{7} \mathrm{O}_{3}: 391.38$, found $390.00(\mathrm{M}-\mathrm{H})^{+}$; anal. calcd for $\mathrm{C}_{19} \mathrm{H}_{17} \mathrm{~N}_{7} \mathrm{O}_{3}$ : (\%) C, 58.31; H, 4.38; N, 25.05; $\mathrm{O}, 12.26$ found: $\mathrm{C}, 58.33 ; \mathrm{H}, 4.42 ; \mathrm{N}, 25.01 ; \mathrm{O}, 12.24$.

$\boldsymbol{N}$-(5,6-Dimethyl-1H-benzo[d]imidazol-2-yl)-2-(4-(3-nitrophenyl)-1H-1,2,3-triazol-1-yl)acetamide (7n). Yellow; (67\%); m.p. $277-279{ }^{\circ} \mathrm{C}$; IR $\nu_{\max }\left(\mathrm{KBr}, \mathrm{cm}^{-1}\right) 3328,3137,1649,1598$, 1389; ${ }^{1} \mathrm{H}$ NMR (400 MHz, DMSO) $\delta 12.08$ (s, 2H), $8.89(\mathrm{~s}, 1 \mathrm{H})$, $8.73-8.63(\mathrm{~m}, 1 \mathrm{H}), 8.33(\mathrm{~d}, J=7.9 \mathrm{~Hz}, 1 \mathrm{H}), 8.21$ (d, $J=7.8$, $1 \mathrm{H}), 7.78(\mathrm{t}, J=8.0 \mathrm{~Hz}, 1 \mathrm{H}), 7.18(\mathrm{~s}, 2 \mathrm{H}), 5.41(\mathrm{~s}, 2 \mathrm{H}), 2.26(\mathrm{~s}$, $6 \mathrm{H}) .{ }^{13} \mathrm{C}$ NMR (101 MHz, DMSO) $\delta 169.67,145.21,135.34$, $134.81,131.18,130.72,128.69,128.38,127.13,126.11$, 124.74, 123.23, 113.77, 53.82, 20.27. ESI-MS: $(\mathrm{m} / \mathrm{z})$ calcd for $\mathrm{C}_{19} \mathrm{H}_{17} \mathrm{~N}_{7} \mathrm{O}_{3}: 391.38$, found $390.00(\mathrm{M}-\mathrm{H})^{+}$; anal. calcd for $\mathrm{C}_{19} \mathrm{H}_{17} \mathrm{~N}_{7} \mathrm{O}_{3}$ : (\%) C, 58.31; H, 4.38; N, 25.05; O, 12.26 found: C, 58.32; H, 4.43; N, 25.02; O, 12.23.

$N$-(1H-Benzo[d]imidazol-2-yl)-3-(1-(2-(cyclohexylamino)-2oxoethyl)-1H-1,2,3-triazol-4-yl)propanamide (10a). White; (46\%); m.p. 328-330 ${ }^{\circ} \mathrm{C}$; IR $\nu_{\max }\left(\mathrm{KBr}, \mathrm{cm}^{-1}\right) 3384,3137,1648$, 1579, 1408; ${ }^{1} \mathrm{H}$ NMR (400 MHz, DMSO) 12.04 (s, 1H), 11.54 (s, $1 \mathrm{H}), 8.32(\mathrm{~d}, 1 \mathrm{H}), 7.81(\mathrm{~s}, 1 \mathrm{H}), 7.48(\mathrm{dd}, J=5.9,3.2 \mathrm{~Hz}, 2 \mathrm{H})$, $7.05(\mathrm{dd}, J=5.9,3.2 \mathrm{~Hz}, 2 \mathrm{H}), 4.98(\mathrm{~s}, 2 \mathrm{H}), 3.84(\mathrm{p}, 1 \mathrm{H}), 2.76(\mathrm{t}$, 2H) $2.61(\mathrm{t}, 2 \mathrm{H}) 2.14-1.18(\mathrm{~m}, 10 \mathrm{H}) .{ }^{13} \mathrm{C}$ NMR $(101 \mathrm{MHz}$, DMSO) $\delta 172.75,165.22,146.48,124.96,124.49,121.61$, 121.67, 121.44, 51.96, 50.83, 32.64, 31.11, 25.06, 24.38, 23.86. ESI-MS: $(\mathrm{m} / \mathrm{z})$ calcd for $\mathrm{C}_{20} \mathrm{H}_{25} \mathrm{~N}_{7} \mathrm{O}_{2}: 395.46$, found $394.00(\mathrm{M}-$ $\mathrm{H})^{+}$; anal. calcd for $\mathrm{C}_{20} \mathrm{H}_{25} \mathrm{~N}_{7} \mathrm{O}_{2}$ : (\%) C, 60.74; $\mathrm{H}, 6.37 ; \mathrm{N}$, 24.79; O, 8.09 found: C, 60.78; H, 6.39; N, 24.77; O, 8.05.

$\mathrm{N}$-(1H-Benzo[d]imidazol-2-yl)-3-(1-(2-oxo-2-(pyridin-2-ylamino)ethyl)-1H-1,2,3-triazol-4-yl)propanamide (10b). White; (63\%); m.p. 286-288 ${ }^{\circ} \mathrm{C}$; IR $\nu_{\max }\left(\mathrm{KBr}, \mathrm{cm}^{-1}\right) 3378,3131,1643$, 1569, 1405; ${ }^{1} \mathrm{H}$ NMR (400 MHz, DMSO) $\delta 12.14(\mathrm{~s}, 1 \mathrm{H}), 11.30$ $(\mathrm{s}, 1 \mathrm{H}), 10.96(\mathrm{~s}, 1 \mathrm{H}), 8.36(\mathrm{~s}, 1 \mathrm{H}), 7.95-7.79(\mathrm{~m}, 3 \mathrm{H}), 7.68-$ $7.57(\mathrm{~m}, 1 \mathrm{H}), 7.53-7.11(\mathrm{~m}, 4 \mathrm{H}), 5.38(\mathrm{~s}, 2 \mathrm{H}), 3.04-2.60(\mathrm{~m}$, $4 \mathrm{H}) .{ }^{13} \mathrm{C}$ NMR (101 MHz, DMSO) $\delta$ 171.92, 165.73, 151.89, 148.61, 145.99, 145.84, 139.15, 138.87, 124.38, 124.30, 121.69, 120.34, 113.96, 52.55, 31.13, 21.07. ESI-MS: $(\mathrm{m} / \mathrm{z})$ calcd for $\mathrm{C}_{19} \mathrm{H}_{18} \mathrm{~N}_{8} \mathrm{O}_{2}: 390.40$, found $389.00(\mathrm{M}-\mathrm{H})^{+}$; anal. calcd for $\mathrm{C}_{19} \mathrm{H}_{18} \mathrm{~N}_{8} \mathrm{O}_{2}$ : (\%) C, 58.45; H, 4.65; N, 28.70; O, 8.20 found: $\mathrm{C}$, $58.49 ; \mathrm{H}, 4.62 ; \mathrm{N}, 28.66 ; \mathrm{O}, 8.23$.

$N$-(1H-Benzo[d]imidazol-2-yl)-4-(1-(2-(cyclopentylamino)2-oxoethyl)-1H-1,2,3-triazol-4-yl)butanamide (11a). White; (62\%); m.p. $261-263{ }^{\circ} \mathrm{C}$; IR $\nu_{\max }\left(\mathrm{KBr}, \mathrm{cm}^{-1}\right) 3372,3131,1660$, 1577, 1420; ${ }^{1} \mathrm{H}$ NMR (400 MHz, DMSO) 12.07 (s, 1H), 11.50 (s, $1 \mathrm{H}), 8.30(\mathrm{~d}, 1 \mathrm{H}), 7.84(\mathrm{~s}, 1 \mathrm{H}), 7.47(\mathrm{dd}, J=5.9,3.2 \mathrm{~Hz}, 2 \mathrm{H})$, $7.07(\mathrm{dd}, J=5.9,3.2 \mathrm{~Hz}, 2 \mathrm{H}), 4.99(\mathrm{~s}, 2 \mathrm{H}), 4.00(\mathrm{p}, 1 \mathrm{H}), 2.81(\mathrm{t}$, 2H) $2.79(\mathrm{~m}, 1 \mathrm{H}), 2.08-1.29(\mathrm{~m}, 11 \mathrm{H}) .{ }^{13} \mathrm{C}$ NMR (101 MHz, DMSO) 172.70, 165.23, 146.47, 124.16, 124.00, 121.61, 121.52, 121.39, 51.98, 51.02, 32.69, 31.14, 25.06, 24.91, 23.85. ESI-MS: $(\mathrm{m} / \mathrm{z})$ calcd for $\mathrm{C}_{20} \mathrm{H}_{25} \mathrm{~N}_{7} \mathrm{O}_{2}: 396.46$, found $395.00(\mathrm{M}-\mathrm{H})^{+}$; anal. calcd for $\mathrm{C}_{20} \mathrm{H}_{25} \mathrm{~N}_{7} \mathrm{O}_{2}$ : (\%) C, 60.74; H, 6.37; N, 24.79; O, 8.09 found: C, 60.79; H, 6.34; N, 24.78; O, 8.08.

$\mathrm{N}$-(1H-Benzo[d]imidazol-2-yl)-4-(1-(2-(cyclohexylamino)-2oxoethyl)-1H-1,2,3-triazol-4-yl)butanamide (11b). White; 
(58\%); m.p. 199-201 ${ }^{\circ} \mathrm{C}$; IR $\nu_{\max }\left(\mathrm{KBr}, \mathrm{cm}^{-1}\right) 3383,3133,1637$, 1566, 1402; ${ }^{1} \mathrm{H}$ NMR (400 MHz, DMSO) 12.09 (s, 1H), 11.57 (s, $1 \mathrm{H}), 8.31(\mathrm{~d}, 1 \mathrm{H}), 7.86(\mathrm{~s}, 1 \mathrm{H}), 7.51(\mathrm{dd}, J=5.9,3.2 \mathrm{~Hz}, 2 \mathrm{H})$, $7.14(\mathrm{dd}, J=5.9,3.2 \mathrm{~Hz}, 2 \mathrm{H}), 4.97(\mathrm{~s}, 2 \mathrm{H}), 3.89(\mathrm{p}, 1 \mathrm{H}), 2.69$ (t, 2H) $2.62(\mathrm{t}, 2 \mathrm{H}), 2.14-1.18(\mathrm{~m}, 12 \mathrm{H}) .{ }^{13} \mathrm{C}$ NMR $(101 \mathrm{MHz}$, DMSO) $\delta 172.71,165.82,146.73,124.83,124.47,121.61$, 121.66, 121.49, 51.95, 50.82, 32.66, 31.17, 27.53, 25.26, 24.40, 23.83. ESI-MS: $(\mathrm{m} / \mathrm{z})$ calcd for $\mathrm{C}_{21} \mathrm{H}_{27} \mathrm{~N}_{7} \mathrm{O}_{2}: 409.48$, found $394.00(\mathrm{M}-\mathrm{H})^{+}$; anal. calcd for $\mathrm{C}_{21} \mathrm{H}_{27} \mathrm{~N}_{7} \mathrm{O}_{2}$ : (\%) C, 61.60; $\mathrm{H}$, $6.65 ; \mathrm{N}, 23.94 ; \mathrm{O}, 7.81$ found: C, 61.64; H, 6.61; N, 23.92; O, 7.83 .

$\mathrm{N}$-(1H-Benzo[d]imidazol-2-yl)-4-(1-(2-oxo-2-(pyridin-2-ylamino)ethyl)-1H-1,2,3-triazol-4-yl)butanamide (11c). White; (68\%); m.p. 258-259 ${ }^{\circ} \mathrm{C}$; IR $\nu_{\max }\left(\mathrm{KBr}, \mathrm{cm}^{-1}\right) 3394,3125$, $1652,1563,1404 ;{ }^{1} \mathrm{H}$ NMR (400 MHz, DMSO) $\delta 12.24(\mathrm{~s}, 1 \mathrm{H})$, $11.54(\mathrm{~s}, 1 \mathrm{H}), 10.97(\mathrm{~s}, 1 \mathrm{H}), 8.37(\mathrm{~s}, 1 \mathrm{H}), 7.97(\mathrm{~m}, 2 \mathrm{H}), 7.74$ $(\mathrm{dd}, J=5.8,3.5 \mathrm{~Hz}, 3 \mathrm{H}), 7.15(\mathrm{~m}, 1 \mathrm{H}), 7.08(\mathrm{~m}, 2 \mathrm{H}), 5.37$ (s, $2 \mathrm{H}), 2.73(\mathrm{t}, 2 \mathrm{H}), 2.59(\mathrm{t}, 2 \mathrm{H}), 1.93(\mathrm{p}, 2 \mathrm{H}) .{ }^{13} \mathrm{C}$ NMR (101 $\mathrm{MHz}, \mathrm{DMSO}) \delta 176.80,165.75,151.90,148.61,146.79$, $133.93,124.47,124.29,121.65,121.45,120.37,116.09$, 113.98, 52.51, 33.55, 31.27, 24.93. ESI-MS: $(\mathrm{m} / \mathrm{z})$ calcd for $\mathrm{C}_{20} \mathrm{H}_{20} \mathrm{~N}_{8} \mathrm{O}_{2}$ : 304.43, found $403.00(\mathrm{M}-\mathrm{H})^{+}$; anal. calcd for $\mathrm{C}_{20} \mathrm{H}_{20} \mathrm{~N}_{8} \mathrm{O}_{2}$ : (\%) C, 59.40; H, 4.98; N, 27.71; O, 7.91 found: $\mathrm{C}$, $59.43 ; \mathrm{H}, 4.96$; N, 27.68; O, 7.93.

$\mathrm{N}$-(1H-Benzo[d]imidazol-2-yl)-4-(1-(4-nitrophenyl)-1H-1,2,3triazol-4-yl)butanamide (11d). Yellow; (59\%); m.p. 263-265 ${ }^{\circ} \mathrm{C}$; IR $\nu_{\max }\left(\mathrm{KBr}, \mathrm{cm}^{-1}\right) 3396,3143,1654,1566,1405 ;{ }^{1} \mathrm{H}$ NMR $(400$ MHz, DMSO) $\delta 12.08$ (s, 1H), 11.61 (s, 1H), 8.93 (s, 1H), 8.51 (d, $J=8.9 \mathrm{~Hz}, 2 \mathrm{H}), 8.32(\mathrm{~d}, J=8.8 \mathrm{~Hz}, 2 \mathrm{H}), 7.43(\mathrm{dd}, J=5.9,3.2 \mathrm{~Hz}$, $2 \mathrm{H}), 7.25-7.12(\mathrm{~m}, 2 \mathrm{H}), 2.83(t, 2 \mathrm{H}), 2.61(\mathrm{t}, 2 \mathrm{H}), 1.98(\mathrm{p}, 2 \mathrm{H})$. ${ }^{13} \mathrm{C}$ NMR (101 MHz, DMSO) $\delta$ 168.72, 148.57, 147.37, 147.71, 137.26, 126.57, 125.63, 124.98, 124.31, 122.14, 113.88, 33.69, 31.73, 24.28. ESI-MS: $(\mathrm{m} / \mathrm{z})$ calcd for $\mathrm{C}_{19} \mathrm{H}_{17} \mathrm{~N}_{7} \mathrm{O}_{3}: 391.38$, found $390.00(\mathrm{M}-\mathrm{H})^{+}$; anal. calcd for $\mathrm{C}_{19} \mathrm{H}_{17} \mathrm{~N}_{7} \mathrm{O}_{3}$ : (\%) C, 58.31; H, 4.38; N, 25.05; O, 12.26 found: C, 58.35; H, 4.41; N, 25.02; O, 12.22 .

4-(1-(2-(Cyclopentylamino)-2-oxoethyl)-1H-1,2,3-triazol-4-yl)$\boldsymbol{N}$-(5,6-dimethyl-1H-benzo[d]imidazol-2-yl)butanamide (12a). White; (47\%); m.p. $252-254^{\circ} \mathrm{C}$; IR $\nu_{\max }\left(\mathrm{KBr}, \mathrm{cm}^{-1}\right) 3377,3148$, 1647, 1582, 1404; ${ }^{1} \mathrm{H}$ NMR (400 MHz, DMSO) $\delta 12.08$ (s, 1H), 11.57 (s, 1H), $10.91(\mathrm{~s}, 1 \mathrm{H}), 8.34(\mathrm{~s}, 1 \mathrm{H}), 7.44(\mathrm{~s}, 2 \mathrm{H}), 4.94(\mathrm{~s}, 2 \mathrm{H})$, $3.61(\mathrm{~m}, 1 \mathrm{H}), 2.65(\mathrm{t}, 2 \mathrm{H}) 2.4-1.86(\mathrm{~m}, 12 \mathrm{H}), 1.67-1.33(\mathrm{~m}, 6 \mathrm{H})$. ${ }^{13} \mathrm{C}$ NMR (101 MHz, DMSO) $\delta$ 172.74, 165.37, 146.38, 124.91, 124.80, 121.49, 121.24, 121.45, 51.96, 51.02, 35.64, 34.45, 32.57, 32.29, 25.05, 24.83. ESI-MS: $(\mathrm{m} / \mathrm{z})$ calcd for $\mathrm{C}_{22} \mathrm{H}_{29} \mathrm{~N}_{7} \mathrm{O}_{2}: 423.51$, found $422.00(\mathrm{M}-\mathrm{H})^{+}$; anal. calcd for $\mathrm{C}_{22} \mathrm{H}_{29} \mathrm{~N}_{7} \mathrm{O}_{2}$ : (\%) C, 62.39; H, 6.90; N, 23.15; O, 7.56 found: C, 62.37; H, 6.88; N, 23.17; O, 7.58 .

4-(1-(2-(Cyclohexylamino)-2-oxoethyl)-1H-1,2,3-triazol-4-yl)$\boldsymbol{N}$-(5,6-dimethyl-1H-benzo[d]imidazol-2-yl)butanamide (12b). White; (46\%); m.p. $282-285^{\circ} \mathrm{C}$; IR $\nu_{\max }\left(\mathrm{KBr}, \mathrm{cm}^{-1}\right) 3393,3127$, 1682, 1582, 1408; ${ }^{1} \mathrm{H}$ NMR (400 MHz, DMSO) $\delta 12.05$ (s, 1H), $11.53(\mathrm{~s}, 1 \mathrm{H}), 10.78(\mathrm{~s}, 1 \mathrm{H}), 8.32(\mathrm{~s}, 1 \mathrm{H}), 7.82(\mathrm{~s}, 2 \mathrm{H}), 4.98(\mathrm{~s}$, $2 \mathrm{H}), 3.54(\mathrm{~m}, 1 \mathrm{H}), 2.64(\mathrm{t}, 2 \mathrm{H}) 2.4-1.5(\mathrm{~m}, 12 \mathrm{H}), 1.31-1.12(\mathrm{~m}$, $8 \mathrm{H}) .{ }^{13} \mathrm{C}$ NMR (101 MHz, DMSO) $\delta$ 172.69, 165.37, 146.42, 124.11, 124.08, 121.19, 121.22, 121.49, 51.98, 51.02, 35.37, $34.27,32.69,32.14,25.06,24.92,23.86$. ESI-MS: $(\mathrm{m} / \mathrm{z})$ calcd for
$\mathrm{C}_{23} \mathrm{H}_{31} \mathrm{~N}_{7} \mathrm{O}_{2}$ : 437.54, found $436.00(\mathrm{M}-\mathrm{H})^{+}$; anal. calcd for $\mathrm{C}_{23} \mathrm{H}_{31} \mathrm{~N}_{7} \mathrm{O}_{2}$ : (\%) C, 63.14; $\mathrm{H}, 7.14 ; \mathrm{N}, 22.41 ; \mathrm{O}, 7.31$ found: $\mathrm{C}$, 63.17; H, 7.11; N, 22.43; O, 7.29.

$N$-(5,6-Dimethyl-1H-benzo $[d]$ imidazol-2-yl)-4-(1-(2-oxo-2(pyridin-2-ylamino)ethyl)-1H-1,2,3-triazol-4-yl)butanamide (12c). White; (45\%); m.p. $273-275{ }^{\circ} \mathrm{C}$; IR $\nu_{\max }\left(\mathrm{KBr}, \mathrm{cm}^{-1}\right)$ 3314, 3127, 1639, 1571, 1407; ${ }^{1} \mathrm{H}$ NMR (400 MHz, DMSO) $\delta 12.45(\mathrm{~s}, 1 \mathrm{H}), 11.54(\mathrm{~s}, 1 \mathrm{H}), 10.96(\mathrm{~s}, 1 \mathrm{H}), 8.44(\mathrm{~s}, 1 \mathrm{H}), 7.47$ $(\mathrm{s}, 2 \mathrm{H}), 5.18(\mathrm{~s}, 2 \mathrm{H}), 2.27(\mathrm{t}, 2 \mathrm{H}), 2.59(\mathrm{~s}, 6 \mathrm{H}), 2.48(\mathrm{t}, 2 \mathrm{H}), 1.78$ (p, 2H). ${ }^{13} \mathrm{C}$ NMR (101 MHz, DMSO) $\delta$ 174.84, 165.71, 150.91, 148.66, 146.19, 133.43, 124.46, 123.27, 121.45, 121.43, 120.37, 116.14, 113.88, 52.54, 33.54, 31.54, 24.97. ESI-MS: $(\mathrm{m} / \mathrm{z})$ calcd for $\mathrm{C}_{22} \mathrm{H}_{24} \mathrm{~N}_{8} \mathrm{O}_{2}$ : 432.48, found $431.00(\mathrm{M}-\mathrm{H})^{+}$; anal. calcd for $\mathrm{C}_{22} \mathrm{H}_{24} \mathrm{~N}_{8} \mathrm{O}_{2}$ : (\%) C, 61.10; H, 5.59; N, 25.91; O, 7.40 found: $\mathrm{C}$, 61.14; H, 5.57; N, 25.87; O, 7.38.

\section{Quorum sensing inhibition assay}

Antibacterial activities of the synthesized compounds were evaluated by using $P$. aeruginosa MH602 lasB reporter strain (PlasB: gfp(ASV)) following the protocol developed by Hentzer et $a l .{ }^{37}$ The production of AHL signals by this reporter strain leads to an increase in product of unstable green fluorescent protein (GFP-ASV) as a function of an active QS system.

AHL dependent GFP expressing $P$. aeruginosa MH602 PlasB-gfp(ASV) harbouring a chromosomal fusion of the lasB promoter expressing $\mathrm{Gfp}(\mathrm{ASV})$ in response to 3-oxododecanoyl HSL strains were cultured overnight in LB10. Strains were diluted $(1: 100)$ in ABT medium supplemented with $0.25 \%$ tryptone and $0.13 \%$ yeast extract and $200 \mu \mathrm{L}$ of aliquots were dispensed to flat bottom 96-well plate wells (Sarstedt Australia). Cultures were supplemented with varying concentrations of synthetic compounds dissolved in DMSO. Control cultures were supplemented with equal amount of DMSO (1\%). Plates were sealed with self-adhesive microplate sealers (TopSeal-A, PerkinElmer) to allow air diffusion and to prevent condensation. Cultures were incubated in a plate reader (EnSight Multimode Plate Reader, PerkinElmer) at $37{ }^{\circ} \mathrm{C}$ with shaking briefly prior to each reading and fluorescence (excitation, $485 \mathrm{~nm}$; emission, 535 $\mathrm{nm}$ ) and OD600 of cultures were measured every 30 min over $20 \mathrm{~h}$. Ampicillin $\left(100 \mu \mathrm{g} \mathrm{mL}{ }^{-1}\right)$ and gentamicin $\left(20 \mu \mathrm{g} \mathrm{mL}^{-1}\right)$ were supplemented to $P$. aeruginosa MH602 cultures.

\section{Cytotoxicity assay}

MTT assay. Cytotoxicity of the novel promising compounds was determined using MTT assay. $457.5 \times 10^{3}$ cells were seeded in 96 well plates and incubated overnight. Cells were treated with synthesized compounds at three concentrations $(50 \mu \mathrm{M}, 25$ $\mu \mathrm{M}$ and $10 \mu \mathrm{M}$ ) in duplicates and incubated for $24 \mathrm{~h} .50 \mu \mathrm{L}$ of $5 \mathrm{mg} \mathrm{mL}{ }^{-1}$ 3-(4,5-dimethylthiazol-2-yl)-2,5-diphenyltetrazolium bromide (MTT; Himedia Laboratories Pvt. Ltd., Mumbai, India) was added and incubated for $4 \mathrm{~h}$. Formazan crystals were dissolved using DMSO and absorbance was measured using Spectramax M4 (Molecular Devices, USA). 


\section{Cell culture and assay procedure}

All the compounds tested for their cytotoxicity against Human Embryonic Kidney (HEK) cell lines (procured from National Centre for Cell Science, Pune, India) were cultured in DMEM (high glucose media: AL007S, Dulbecco's modified eagle medium) with $10 \%$ fetal bovine serum (FBS) and 1\% antibiotic (Pen strep: A001) incubated at $37{ }^{\circ} \mathrm{C}$ and $5 \% \mathrm{CO}_{2}$ atmosphere. All reagents were purchased from Himedia Laboratories Pvt. Ltd., Mumbai, India. Cells were seeded in a 96-well plate (Eppendorf 0030730119) with $100 \mu \mathrm{L}$ of cell suspension containing $10^{4}$ cells per well and incubated overnight. The DMSO solutions of the synthesized compounds and BG45 were prepared and they were further diluted to their respective concentrations of $25 \mu \mathrm{M}, 50 \mu \mathrm{M}$, and $100 \mu \mathrm{M}$ with the DMEM complete media. The cells were then treated with $100 \mu \mathrm{L}$ of the compound solutions made in media along with a blank control containing DMSO in medium and BG45 as positive control and were incubated for $24 \mathrm{~h}$. The culture medium was aspirated and subsequently, $50 \mu \mathrm{L}$ of $5 \mathrm{mg} \mathrm{mL} \mathrm{m}^{-1}$ concentrated solution of MTT (3-(4,5-dimethylthiazol-2-yl)-2,5-diphenyltetrazolium bromide) in phenol red free DMEM was prepared and added in each well and further incubated for $3 \mathrm{~h}$ for the formation of formazan crystals. Later, $100 \mu \mathrm{L}$ DMSO was added to the culture after aspirating media in the wells to dissolve the formazan crystals and the absorbance was measured using multi-well plate reader Spectramax (Molecular Devices, USA) at two different wavelengths of $570 \mathrm{~nm}$ and $650 \mathrm{~nm}$. The \% cell viability was calculated as a fraction of absorbance obtained from the treated cells from the absorbance of untreated control cells. $^{37}$

\section{Conflicts of interest}

There are no conflicts of interest to declare.

\section{Acknowledgements}

KVGCS and SM thank DBT, New Delhi [BT/IN/Spain/39/ SMl2017-18] for providing financial support. The financial assistance provided by DIST FIST grant (SR/FST/CSI-240/2012), New Delhi is gratefully acknowledged. SS thanks CSIR for providing SRF fellowship. Central analytical lab facilities of BITS Pilani Hyderabad campus are gratefully acknowledged. We are also thankful to UNSW School of Biotechnology and Biomolecular Sciences and UNSW School of Medical Sciences for their support.

\section{References}

1 M. Boyer and F. Wisniewski-Dyé, FEMS Microbiol. Ecol., 2009, 1, 1-19.

2 G. D. Geske, J. C. O'Neill, D. M. Miller, M. E. Mattmann and H. E. Blackwell, J. Am. Chem. Soc., 2007, 129, 13613-13625.

3 D. McDougald, W. H. Lin, S. A. Rice and S. Kjelleberg, Biofouling, 2006, 22, 133-144.
4 M. E. Mattmann and H. E. Blackwell, J. Org. Chem., 2010, 75, 6737-6746.

5 A. Eberhard, A. L. Burlingame, C. Eberhard, G. L. Kenyon, K. H. Nealson and N. J. Oppenheimer, Biochemistry, 1981, 20, 2444-2449.

6 D. A. Higgins, M. E. Pomianek, C. M. Kraml, R. K. Taylor, M. F. Semmelhack and B. L. Bassler, Nature, 2007, 45, 883886.

7 M. M. Marketon, M. R. Gronquist, A. Eberhard and J. E. González, J. Bacteriol., 2002, 184, 5686-5695.

8 https://www.cdc.gov/hai/organisms/gram-negativebacteria.html.

9 H. A. Khan, F. K. Baig and R. Mehboob, Asian Pac. J. Trop. Med., 2017, 7, 478-482.

10 N. A. Bhawsar and M. Singh, Int. J. Adv. Res., 2014, 6, 778783.

11 R. Manfredi, A. Nanetti, M. Ferri and F. Chiodo, Eur. J. Clin. Microbiol. Infect. Dis., 2000, 19, 248-253.

12 A. R. Hauser and J. Rello, Severe Infections Caused by Pseudomonas Aeruginosa, 2003, http:/www.springer.com/ gp/book/9781402074219(book).

13 C. Van Delden and B. H. Iglewski, Emerging Infect. Dis., 1998, 4, 551-560.

$14 \mathrm{http} / /$ www.who.int/medicines/publications/WHO-PPLShort_Summary_25FebET_NM_WHO.pdf.

15 http://www.who.int/news-room/fact-sheets/detail/antibioticresistance.

16 L. Fulghesu, C. Giallorenzo and D. Savoia, J. Chemother., 2007, 19, 388-391.

17 R. Kerstin, S. Anke and H. Volkhard, Perspect. Med. Chem., 2016, 8, 1-15.

18 N. Ni, M. Li, J. Wang and B. Wa, Med. Res. Rev., 2009, 29, 65124.

19 C. Y. Chang, T. Krishnan, H. Wang, Y. Chen, W. F. Yin, Y. M. Chong, L. Y. Tan, T. M. Chong and K. G. Chan, Sci. Rep., 2014, 4, 1-8.

20 Y. Peng, J. Bi, J. Shi, Y. Li, X. Ye, X. Chen and Z. Yao, Am. J. Infect. Control, 2014, 42, 1308-1311.

21 L. C. Antunes, R. B. Ferreira, M. M. Buckner and B. B. Finlay, Microbiology, 2010, 156, 2271-2282.

22 P. Williams and M. Cámara, Curr. Opin. Microbiol., 2009, 12, 182-191.

23 https://www.springer.com/in/book/9788132219811.

24 S. Srinivasarao, S. Nizalapur, T. T. Yu, D. S. Wenholz, P. Trivedi, B. Ghosh, K. Rangan, N. Kumar and K. V. G. Chandra Sekhar, ChemistrySelect, 2018, 3, 91709180.

25 J. Musk, J. Dinty and P. J. Hergenrother, Curr. Med. Chem., 2006, 13, 2163-2177.

26 H. O. Sintim, J. A. Smith, J. Wang, S. Nakayama and L. Yan, Future Med. Chem., 2010, 2, 1005-1035.

27 J. J. Richards and C. Melander, Anti-Infect. Agents Med. Chem., 2009, 4, 295-314.

28 R. Frei, A. S. Breitbach and H. E. Blackwell, Angew. Chem., Int. Ed., 2012, 51, 5226-5229.

29 J. D Moore, J. P. Gerdt, N. R. Eibergen and H. E. Blackwell, ChemBioChem, 2014, 3, 435-442. 
30 D. Dheer, V. Singh and R. Shankar, Bioorg. Chem., 2017, 71, 30-54.

31 D. M. Stacy, S. T. Le Quement, C. L. Hansen, J. W. Clausen, T. T. Nielsen, J. W. Brummond, M. Givskov, T. E. Nielsen and H. E. Blackwella, Org. Biomol. Chem., 2013, 11, 938-954.

32 M. R. Hansen, T. H. Jakobsen, C. G. Bang, A. E. Cohrt, C. L. Hansen, J. W. Clausen, S. T. Le Quement, T. T. Nielsen, M. Givskov and T. E. Nielsen, Bioorg. Med. Chem., 2015, 23, 1638-1650.

33 G. Brackman, M. Risseeuw, S. Celen, P. Cos, L. Maes, H. J. Nelis, S. V. Calenbergh and T. Coenye, Bioorg. Med. Chem., 2012, 20, 4737-4743.

34 H. Nagesh, S. Singireddi, A. Suresh, S. Nizalapur, S. Murugesan, K. Kanneboina, N. Kumar and K. V. G. Chandra Sekhar, ChemistrySelect, 2018, 3, 75657571.

35 S. Nizalapur, O. Kimyon, E. Yee, M. M. Bhadbhade, M. Manefield, M. Willcox, D. S. Black and N. Kumar, Org. Biomol. Chem., 2017, 15, 5743-5755.
36 https://patents.google.com/patent/WO2012174312A3/en.

37 M. Hentzer, K. Riedel, T. B. Rasmussen, A. Heydorn, J. B. Andersen, M. R. Parsek, S. A. Rice, L. Eberl, S. Molin and N. Høiby, Microbiology, 2002, 148, 87-102.

38 J. Van Meerloo, G. J. Kaspers and J. Cloos, Methods Mol. Biol., 2011, 731, 237-245.

39 Qikprop, Schrödinger, LLC, New York, version 3.8, 2013.

40 S. Chander, A. Penta and S. Murugesan, J. Pha. Res., 2014, 8, 552-562.

41 Qikprop, User Manual, Schrödinger, LLC, version 4, 2014, ch. 1, pp. 2-5.

42 W. L. Jorgensen and E. M. Duffy, Prediction of drug solubility from Monte Carlo simulations, Bioorg. Med. Chem. Lett., 2000, 10, 1155-1158.

43 Glide, Schrödinger, LLC, New York, version 5.9, 2013.

44 L. K. Williams, C. Li, S. G. Withers and G. D. Brayer, J. Med. Chem., 2012, 55, 10177-10186. 